\title{
ALTERNATIVE CARE IN SOUTH AFRICA
}

\author{
Glynis van der Walt \\ BJuris LLB LLM \\ Senior Lecturer, Nelson Mandela University
}

SUMMARY

Currently, South Africa has an estimated 5,2 million abandoned children in need of care. Facing the highest rate of deaths worldwide from HIV/AIDS, and as a developing country, many children are left in need of care. The current article considers the status of alternative care in South Africa in light of the State's ability to provide appropriate alternative care for those in need thereof.

\section{INTRODUCTION}

Alternative care, whether permanent in nature or a temporary solution, is defined as the care that is provided where the child's biological family is unable to provide adequate care for the child concerned. ${ }^{1}$ Alternative care in this sense includes both formal and informal care of children but excludes parental care by the biological parent or parents. ${ }^{2}$ It is submitted that "alternative care" has both a wider and narrower meaning. In the wider sense it refers to care not provided by the biological core family, and accordingly includes all forms of adoption, both domestic and intercountry. This chapter seeks to define the various forms of alternative care (in the narrow sense - that is, excluding adoption and intercountry adoption) that are available in South Africa.

In the narrower sense, alternative care includes all forms of care options that are temporary in nature, and includes foster care, supported independent living, and residential care. ${ }^{3}$ Kinship care is extraordinary because while it is recognised as a means of alternative care, it is generally not temporary in nature. Alternative care in the wider sense, that is, alternative care that includes a permanent solution for the child concerned, forms the basis of this research. In order to have a full understanding as to care that caters for the best interests of the South African child, all forms of care, temporary and permanent in nature, must be considered. While

\footnotetext{
Assim Understanding Kinship Care of Children in Africa: A Family Environment or an Alternative Care Option? (2013) 118. Assim defines "alternative care" as that care that "indicates the provision of care other than parental care to children deprived of their family environment, temporarily or permanently, but with such alternatives possessing the elements of care".

2 See UNDP Beyond the Midpoint: Achieving the Millennium Developmental Goals (2010). S 167 of the Children's Act 38 of 2005 (hereinafter "the CA").
} 
alternative care is also considered in instances following a decision of the criminal justice system, this research is restricted to alternative care for those children who are orphaned or abandoned, and who are declared to be in "need of care and protection". As a general rule, these alternative care options are by their nature characterised as temporary or impermanent. The terms "temporary" or "impermanent" are used for the purposes of this research to refer to most of the potential alternative solutions available in South Africa for a child who is not able to be cared for by his or her parents. An exception to the typical temporary nature of such alternative care is found in the instance of the care of the child by the extended family (also referred to as "kinship care"). In South Africa, care of an abandoned or orphaned child by a relative, or relatives, is common and well established. Kinship care is, as a general rule, permanent in nature.

Potential temporary forms of alternative care provided for in the Care Act (CA) include foster care (including cluster foster care), temporary safety shelters, and care in Child and Youth Care Centres (CYCCs). Care for children in a Child-headed Household $(\mathrm{CHH})$ is also a reality in South Africa. For the purposes of this research, consideration of care in temporary safe care shelters is excluded. Alternative care options are considered in light of the numbers of children in such care, how the rights of such children are catered for, the quality of care received and concerns with respect to the care provided. Every child has the right to have his or her best interests considered of paramount importance when such a determination of placement is made. Regard is had to the effectiveness of the type of placements with specific consideration of the positive and negative effects of the form of care. Where available, reference will be made to the latest available statistics for each form of alternative care. All means have been attempted to acquire the most recent statistics.

According to the latest available statistics, South Africa was home to an estimated 18.5 million children in 2014, and of these, 4.5 million children live with neither of their parents. ${ }^{4}$ In 2014, Blackie reported that South Africa had approximately 5.2 million orphaned children, ${ }^{5}$ an increase of 30 per cent in the number of orphaned children from 2004. ${ }^{6}$ Furthermore, it is estimated that 150000 children are living in $\mathrm{CHHs}^{7}$ and that more than 13000 children live in residential care facilities. ${ }^{8}$ An estimated 345 registered CYCCs $^{9}$ provide care for 21000 children. ${ }^{10}$ While precise statistics are difficult to obtain approximately 10000 children were estimated to be living on the

4 Blackie "Fact Sheet on Child Abandonment Research in South Africa" (2014) http://www.adoptioncoalitionsa.org/wp-content/uploads/2014/05/Fact-Sheet-Research-onChild-Abandonment-in-South-Africa_Final2.pdf (accessed 2017-05-15).

5 Ibid.

6 Blackie http://www.adoptioncoalitionsa.org/wp-content/uploads/2014/05/Fact-SheetResearch-on-Child-Abandonment-in-South-Africa_Final2.pdf. There is no certainty as to the number of unregistered children's homes operating in South Africa.

Ibid.

8 Blackie Sad, Bad and Mad: Exploring Child Abandonment in South Africa (2015) 8.

Formerly referred to as "children's homes".

10 UNICEF "Protection for Orphans and Vulnerable Children" https://www.unicef.org/southafrica/ protection_6633.html (accessed on 2017-03-11). 
streets in South Africa in 2014. ${ }^{11}$ There are no current statistics available concerning children abandoned in South Africa annually but the National Adoption Coalition ${ }^{12}$ reports that the number of abandoned children has increased significantly over the past few years. ${ }^{13}$

These statistics and reports paint a bleak picture of the overall state of abandoned and orphaned children in South Africa. However, since the advent of democracy, the discourse on a child's rights has focused on the realisation of the child as a bearer of rights. ${ }^{14}$ The State bears the obligation to protect and promote the well-being of its children. South Africa's commitment to this goal is evident firstly within the provisions of the Constitution, international law and relevant national legislation.

While it is generally accepted that every effort is required to support and maintain the family as a unit so as to avoid separating family members ${ }^{15}$ and that only compelling reasons should lead to the removal of any child from his or her biological family, ${ }^{16}$ the ideal is difficult to attain in a developing country such as South Africa. ${ }^{17}$ Abject poverty in South Africa is common, and the impact it has on the ability of a parent to care for his or her child, cannot be ignored. Högbacka refers to the economic crisis facing families in South Africa where mothers often are forced to relinquish their child or children simply because they have no other alternative or means to care for such child or children, notwithstanding the fact that social workers often try to assist such impoverished families by seeking employment or extra funding for the family. ${ }^{18}$ Providing an alternative family unit is also not easily achieved as national adoption statistics are low and on the decline, despite the fact that an increasing number of orphaned and abandoned

11 Mokomane, Rochat and The Directorate "Adoption in South Africa: Trends and Patterns in Social Work Practice" 201217 Child and Family Social Work 347.

12 Blackie http://www.adoptioncoalitionsa.org/wp-content/uploads/2014/05/Fact-SheetResearch-on-Child-Abandonment-in-South-Africa_Final2.pdf.

13 Blackie http://www.adoptioncoalitionsa.org/wp-content/uploads/2014/05/Fact-SheetResearch-on-Child-Abandonment-in-South-Africa_Final2.pdf. According to Blackie, Child Welfare, South Africa reports that approximately 3500 babies were abandoned in South Africa during 2010.

14 South African Human Rights Commission "Twenty-five Years of Children's Rights" (2014) https://www.sahrc.org.za/index.php/sahrc-media/news/item/58-twenty-five-years-ofchildrens-rights (accessed 2017-12-07). Refer to Chapter 2 in this respect.

15 Perumal and Kasiram "Children's Homes and Foster Care: Challenging Dominant Discourses in South African Social Work Practice" 2008 44(2) Social Work/Maatskaplike Werk 159. The authors opine that considering the decline in the traditional family environment in South Africa owing to a number of factors, including HIV/AIDS, poverty and unemployment, whether traditional family care should always be prioritised as a placement of first option, is questionable. The authors refer to Clough in support of this view: "There is a widely held belief that families are the ideal places in which to bring up children or indeed in which any of us, but particularly the dependent, should live. The myth that life is best in families persists in spite of the fact that families are not perfect."

16 Schäfer Child Law in South Africa: Domestic and International Perspectives (2011) 453. In Kleynhans v Kleynhans (EC) (unreported) 30/07/2009 Case no 2256/2008 15, the Eastern Cape High Court refused an application to have minor children removed from their maternal care, pending a "family re-integration" process.

17 Perumal and Kasiram 2008 44(2) Social Work/Maatskaplike Werk 161.

18 Högbacka "Maternal Thinking in the Context of Stratified Reproduction: Perspectives of Birth Mothers from South Africa" Gibbons and Rotabi (eds) Intercountry Adoption: Policies, Practices and Outcomes (2013) 152. 
children are being left destitute and in need of care. ${ }^{19}$ As a result, the number of children placed in temporary alternative care is increasing. As long ago as the beginning of the twentieth century, Swedish feminist and author Ellen Key called for the new century to be recognised as the "century of the child". ${ }^{20}$ Thus, the principle of the "best interests of the child" was introduced at the turn of the nineteenth century. ${ }^{21}$ This principle entails considering all possible advantages or disadvantages for a child before a determination affecting that child is made and determining what relevant authorities must do to ensure that the child's best interests are indeed met. ${ }^{22}$ The first appearance of the concept in an international human rights instrument was in the 1959 Declaration of the Rights of the Child. ${ }^{23}$ Principle 2 of the 1959 Declaration includes the following:

"The child shall enjoy special protection, and shall be given opportunities and facilities." 24

Children are vulnerable members of society, and the state and its relevant authorities are required to recognise and protect their rights at all times. Following South Africa's ratification of the relevant declarations and covenants on alternative care, obligations were incurred by South Africa to enact domestic legislation compliant with international principles. When placing a child in alternative care, both international and national law recognises that placement of a child in alternative care is viewed as less desirable than maintaining or reunifying a family. ${ }^{25}$ The responsible authorities involved in making a determination face the challenge of attaining the best match for a child "in the face of deprived families and inadequate infrastructural support". ${ }^{26}$ With this in mind, the various forms of alternative care that are provided for in South Africa are discussed.

As kinship care differs from other impermanent forms of care, it will be considered separately within this article. Impermanent forms of care will be discussed first and kinship care will follow.

19 National Adoption Coalition "Fact Sheet - Research on Child Abandonment in South Africa" New Research on Child Abandonment and Declining Adoption Rates (2014).

20 Ellen Karolina Sofia Key (11 December 1849-25 April 1926); Key The Century of the Child 1900 (translated into English 1909); Hayes Children's Rights-Whose Right? A Review of Child Policy Development in Ireland (2016) 16.

21 Boezaart Child Law in South Africa (2018) 110; Woodhouse "Child Custody in the Age of Children's Rights: The Search for a Just and Workable Standard" 1999 33(3) Family Law Quarterly 815; Fuentes and Domínguez "The Best Interests of the Minor as a Principle of Interpretation in Mexican Civil Law" 2015 VII(2) Mexican Law Review 85.

22 Chidi The Constitutional Interpretation of the "Best Interests" of the Child and the Application thereof by the Courts (LLM dissertation, University of Limpopo) 2014.

23 Adopted by the United Nations General Assembly Resolution 1386 (XIV) of 10 December 1959. This Declaration forms the basis of the CRC that was adopted 30 years later, on the 20 November. The Declaration begins with a short Preamble stating that humankind owes the child the best it has to give, and calls upon all men and women of all Nations to accept their duty to care for children.

24 Cantwell "The Best Interests of the Child in Intercountry Adoption" 2014 UNICEF 9.

25 Couzens "A very long Engagement: The Children's Act 38 of 2005 and the 1993 Hague Convention on The Protection of Children and Cooperation in respect of Intercountry Adoption" 2009 12(1) PER/PELJ 63.

26 Perumal and Kasiram 2008 44(2) Social Work/Maatskaplike Werk 164. 


\section{Legislative provisions concerning alternative care}

A brief consideration of the legislation relevant to the recognition and protection of a child in need of alternative care in South Africa follows. Constitutional provisions will be considered before the reference is made to national legislative protection.

\section{1 (i) Constitutional provisions protecting children in need of alternative care}

The Constitution, as the supreme law of South Africa, places emphasis on the following three children's rights:

- the right to family care, ${ }^{27}$ parental care or appropriate alternative care; ${ }^{28}$

- the right to social services; ${ }^{29}$ and

- the right to protection from abuse, neglect, maltreatment and degradation. ${ }^{30}$

Section 28(1) is clear in imposing an obligation on the State to care for its abandoned and orphaned children. These rights must be considered in the context of the principle that a child's best interests ${ }^{31}$ are of paramount importance when making any determination regarding a child. ${ }^{32}$ In light of section 27(1)(c), read with section 28(1)(c), the Constitution sets certain minimum mandatory standards pertaining to socio-economic rights in an attempt to protect the rights of a child. ${ }^{33}$ These standards relate to the provision of social security, social assistance and social services. As such, the State has a constitutional obligation to provide social assistance to those who are "unable to support themselves and their dependants". ${ }^{34}$ In light hereof, the government has created three categories of social grants, and these are aimed at alleviating at least some of the financial burdens that children have. These grants include the Child Support Grant (CSG); the Foster Care Grant (FCG); and the Care Dependency Grant (South Africa) (CDG).

In terms of section 28(2) of the Constitution, provision is made to ensure that "the best interests of the child are of paramount importance in every

27 S 28(1)(b) of the Constitution. Residential care includes a number of arrangements, including small-group homes, children's villages and institutional care, where children are cared for collectively in large groups.

$28 \mathrm{~S} 28(1)(\mathrm{b})$ of the Constitution.

29 S 28(1)(c) of the Constitution.

30 S 28(1)(d) of the Constitution.

31 A flexible standard that takes into account the relevant factors for the individual child as well as all other rights of the child.

32 S 28(2) of the Constitution.

33 In their article, Mbazira and Sloth-Nielsen "Incy Wincy Spider went Climbing up Again Prospects for Constitutional (Re) interpretation of Section 28(1)(c) of the South African Constitution in the Next Decade of Democracy" 20072 Speculum Juris 147, opine that s 28(1)(c) of the Constitution should be classified socio-economic rights clause, but rather as a constitutional provision for child protection.

$34 \mathrm{~S} 27(1)(\mathrm{c})$. 
matter concerning the child". To ensure that this constitutional imperative is met, the best interests of the child must be considered as the starting point when making a determination regarding his or her placement.

\section{1 (ii) National legislation}

A consideration of relevant national legislation follows.

\section{1(ii)(a) The Children's Act 38 of 2005 (CA)}

Chapter 11 of the CA provides for general regulation of alternative care of an orphaned or abandoned child (OVCs). In terms of the CA, the court must first consider a report on the circumstances of a child, drawn up by the relevant social worker. ${ }^{35}$ The court concerned may make various orders if it finds a child to be "in need of care and protection". ${ }^{36}$

One of the advances of the CA is that it introduces a range of options for the courts that were not available under the Child Care Act of 1983 (CCA). While the CA promotes family and kinship care whenever this is an option for any OVC, institutionalisation remains an option of last resort in the hierarchy of preferred options. ${ }^{37}$ If a court confirms the social worker's finding (that a child is in need of care), it may make an appropriate order based on what is deemed to be in the best interests of the child under consideration.

\section{1 (ii)(b) A child in "need of care"}

In order to be considered for alternative care, provisions in the CA set the requirement that such a child must be found to be in "need of care and protection". Regulations published in terms of the CA set out all the factors that a presiding officer should consider before concluding that a child is in need of care and protection. The CA has expanded the list of factors that could be taken into account under the CCA. In terms of section 150 of the CA, a child is deemed to be "in need of care and protection" where the child:

(a) has been abandoned or orphaned and is without any visible means of support;

(b) displays behaviour that the parent or caregiver cannot control;

(c) lives or works on the streets or begs for a living;

(d) is addicted to dependence-producing substances and is without any support to obtain treatment for such dependency;

(e) has been exploited or lives in circumstances that expose the child to exploitation;

(f) lives in or exposed to circumstances, which may seriously harm that child's physical, mental or social well-being;

(g) may be at risk if returned to the custody of the parent, guardian or caregiver of the child as there is a reason to believe that he or she will

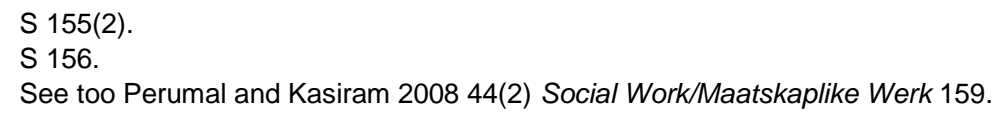


live or be exposed to circumstances, which may seriously harm the physical, mental or social well-being of the child;

(h) is in a state of physical or mental neglect; or

(i) is being maltreated, abused, deliberately neglected or degraded by a parent, a caregiver, a person who has parental responsibilities and rights or a family member of the child or by a person under whose control the child is.

Furthermore, the CA provides that where it becomes apparent that a child is a victim of child labour or is living in a $\mathrm{CHH}$, a social worker is required to investigate the circumstances of each case, to determine if such child is in need of care and protection. In terms of the provisions of the CA, the fact that a child is abandoned or orphaned does not necessarily mean that the child is deemed to be in need of care and protection. The problem lies in the wording of section 150(1)(a), which states that a child is in need of care and protection if the child "has been abandoned or orphaned and is without any visible means of support" (author's own emphasis). In essence, the question at the centre of the wording of section 150(1)(a) is one of support from the state where such child has been identified to be in need of care.

\section{1 (ii)(c) The Social Assistance Act 13 of 2004 (SAA)}

To address the needs of children, especially in the context of the HIV/AIDS pandemic in South Africa, the Department of Social Development (DSD) identified the benefit of providing social security grants to alleviate suffering and provide for the needs of children who were orphaned. In terms of section 8 of the SAA, a foster parent is eligible for an FCG and such foster parent is considered to be the primary caregiver of the child concerned. The foster parent is entitled to receive the FCG for as long as such child (subject to the provisions of section 5 ) is in need of care. ${ }^{38}$ The child concerned must also be "placed in his or her custody". ${ }^{39}$ It is a requirement that the "foster parent is a South African citizen, a permanent resident or a refugee." 40 The common thread for the provision of social security in the SAA is the focus on the provision of grants to alleviate poverty and increase the likelihood of "family care" for children who have been orphaned, on the basis that children without parents are "in need of care". Media reports as of July 2018, have emphasised the plight of those reliant on the grant system. In an attempt to correct existing problems within the system with regards to successfully effecting payment to grant receivers, the Department effected changes to its mode of payment. This has proved disastrous, leaving those who are totally reliant on receiving a grant, unable to access their payment thereof. While the Department of Social Welfare has noted its apologies and concerns, little has been done to assist those who have been left without any financial resource. The current situation is reflective of a system that has faced many challenges over the past years, is ineffective, and which remains overburdened and on the verge of collapse. This does little to quell one's

\footnotetext{
S 8(a).

S 8.

40 Western Cape Government "A Useful Guide for Refugees, Migrants and Asylum Seekers" (2013) https://www.westerncape.gov.za/text/2013/June/local-government-refugee-guidejune.pdf (accessed 2018-04-19).
} 
concerns for the children, and those who care for them, that fall under the auspices and care of the Department of Child Welfare in South Africa.

\section{Impermanent alternative care solutions}

Various temporary or impermanent alternative care solutions are available to an abandoned or orphaned South African child in South Africa. These include foster care, cluster foster care, child-headed households and child and youth care centres, and these are discussed in more detail below. However, all these care options share significant challenges. They are poorly resourced and managed.

Our welfare services seem to be in disarray: they are under-capacitated in every way - not enough staff, not enough cars, offices without computers. The system is still largely paper-based, and this means that cases cannot be properly tracked or referred. The few social workers there are, are rushing around trying to deal with the foster care backlog, although this mainly involves orphaned children who are living quite safely with relatives. In the meantime, cases referred from SAPS are not followed up, and those are the really urgent ones - and only the tip of the iceberg as most cases of abuse don't get reported at all.

According to research done by UNICEF:

- There is a lack of comprehensive statistical data on the children in formal alternative care.

- There remains a lack of any support system when children who have been in alternative care during their childhood attain the age of majority; alternative care then ceases.

Further impacting on the child welfare system is the fact that the CA defines a child as "a person under the age of 18 ". ${ }^{41}$ Within the provisions of the CA, not only is the definition of a "child" broader than the CA's predecessor but the provisions themselves are more comprehensive, and also sanction designated social workers to provide services to non-South African children who happen to be in the Republic and are in need of care and protection. ${ }^{42}$ It is not surprising that the DSD finds itself under great pressure to fulfil its commitments.

A number of factors also have a more direct impact on particular forms of alternative care. These are discussed below.

\section{1 (i) Foster care}

Foster care is an integral component of the South African alternative care system. For the purposes of this research, foster care is the placement of a child needing to be removed from the parental home into the custody of a suitable family or persons willing to be foster parents. In South Africa, a child is deemed legally to be in foster care if the child concerned has been placed

S 1.

42 Sibanda and Lombard "Challenges Faced by Social Workers Working in Child Protection Services in Implementing the Children's Act 38 of 2005" 2015 51(3) Social Work/Maatskaplike Werk 334. 
in the care of a person who is not the parent or guardian of such child, ${ }^{43}$ and the placement is made as a result of:

- $\quad$ an order of a children's court, ${ }^{44}$ or

- a transfer in terms of section 171 of the CA. ${ }^{45}$

Although foster care is well known in South Africa, it was not until the CA was enacted that this type of alternative care was defined legally. Chapter 12 of the CA contains the provisions relating to foster care. For the purposes of this research, the study is limited to foster care for a child deemed to be in need of "care and protection" as defined in section 150 of the CA.

The CA determines the aims of foster care as follows:

- to protect and nurture OVCs by providing a safe, healthy environment that gives the positive support every child needs;

- to promote the goals of permanency planning, the priority at all times being to attempt to reunify the family; 46 and

- where family reunification is not a viable option, to connect OVCs to other safe and nurturing family relationships. ${ }^{47}$

Currently, the suitability and viability of foster care of an abandoned South African child must be considered in light of the principle of the placement being in the best interests of the child concerned.

Carter and Van Breda report that by 2014, foster placements accounted for over half a million $(530357)$ children in alternative care in South Africa. ${ }^{48}$ This conclusion was based on the number of FCGs paid to foster children during that period. ${ }^{49}$ Large numbers of children are placed in foster care as it is generally considered to be the "next-best option" where a child is not able to remain in the care of his or her own family. ${ }^{50}$ However, the huge numbers of children needing such care has proved challenging; the system has become overburdened and is said to be on the brink of collapse. ${ }^{51}$ An indication of the large numbers of children in need of care, and receiving foster care is evident in the Table below. Table 1 provides statistics on children who were recipients of FCGs from 2010 to 2016. These are

43 Certain parental rights and obligations remain with the biological parents of the child. An example hereof is found by the fact that guardianship is not automatically transferred to the foster parents through the granting of an order of foster care.

$44 \mathrm{~S} 180(1)(\mathrm{a})$ of the CA.

$45 \mathrm{~S} 180(1)(\mathrm{b})$ of the CA.

$46 \mathrm{~S} 181(\mathrm{~b})$ of the CA.

47 Ibid.

48 Carter and Van Breda "The Design of a Protocol for Assessing Prospective Foster Parents in South Africa" 2016 52(2) Social Work/Maatskaplike Werk 208.

49 South African Social Security Agency "A Statistical Summary of Social Grants in South Africa" (31 May 2014) http://www.sassa.gov.za/index.php/statistical-reports?start=36 (accessed 2017-06-23).

50 Breen "Policy Brief: Foster Care in South Africa: Where To From Here?" (2015) http://children.pan.org.za/sites/default/files/publicationdocuments/Child\%20Welfare\%20 Policy\%20Brief-\%20Foster\%20Care\%20March\%202015.pdf 15 (accessed 2017-02-28); Van der Riet Foster Care: The Experiences of Birth Children (Master of Social Work dissertation, UNISA) 20093.

51 Breen http://children.pan.org.za/sites/default/files/publicationdocuments/Child\%20Welfare \% 20Policy\%20Brief-\%20 Foster\%20Care\%20March\%202015.pdf 1. 
indicated with reference to the province in which the child lives and the FCG amount received. ${ }^{52}$

\section{Table 1: The number of children receiving the FCG, 2010-2016}

\begin{tabular}{|l|c|c|c|c|c|c|c|}
\hline \multirow{2}{*}{ Province } & \multicolumn{7}{|c|}{ Number of child beneficiaries at end March } \\
\cline { 2 - 8 } & $\mathbf{2 0 1 0}$ & $\mathbf{2 0 1 1}$ & $\mathbf{2 0 1 2}$ & $\mathbf{2 0 1 3}$ & $\mathbf{2 0 1 4}$ & $\mathbf{2 0 1 5}$ & $\mathbf{2 0 1 6}$ \\
\hline $\begin{array}{l}\text { Eastern } \\
\text { Cape }\end{array}$ & 100810 & 108389 & 116826 & 117231 & 116172 & 115849 & 110007 \\
\hline Free State & 44478 & 43764 & 43311 & 41317 & 39178 & 37985 & 35426 \\
\hline Gauteng & 62023 & 59477 & 56451 & 58722 & 55027 & 53411 & 51568 \\
\hline $\begin{array}{l}\text { KwaZulu- } \\
\text { Natal }\end{array}$ & 141404 & 134181 & 142114 & 135442 & 125702 & 118505 & 106755 \\
\hline Limpopo & 54314 & 54701 & 56066 & 58953 & 58571 & 57694 & 52272 \\
\hline $\begin{array}{l}\text { Mpuma- } \\
\text { langa }\end{array}$ & 26164 & 27366 & 32886 & 35359 & 33877 & 34260 & 33735 \\
\hline $\begin{array}{l}\text { North } \\
\text { West }\end{array}$ & 38656 & 41405 & 45634 & 42215 & 40726 & 37984 & 36001 \\
\hline $\begin{array}{l}\text { Northern } \\
\text { Cape }\end{array}$ & 14716 & 14999 & 14456 & 14342 & 14307 & 14513 & 14075 \\
\hline $\begin{array}{l}\text { Western } \\
\text { Cape }\end{array}$ & 28195 & 28592 & 29003 & 28578 & 28495 & 29573 & 30176 \\
\hline $\begin{array}{l}\text { South } \\
\text { Africa }\end{array}$ & $\mathbf{5 1 0 7 6 0}$ & $\mathbf{5 1 2 ~ 8 7 4}$ & $\mathbf{5 3 6 7 4 7}$ & $\mathbf{5 3 2 1 5 9}$ & $\mathbf{5 1 2 ~ 0 5 5}$ & $\mathbf{4 9 9 7 7 4}$ & $\mathbf{4 7 0 ~ 0 1 5}$ \\
\hline $\begin{array}{l}\text { FCG } \\
\text { amount }\end{array}$ & $\mathrm{R} \mathrm{710}$ & $\mathrm{R} \mathrm{740}$ & $\mathrm{R} \mathrm{770}$ & $\mathrm{R} 800$ & $\mathrm{R} 830$ & $\mathrm{R} 860$ & $\mathrm{R} 890$ \\
\hline
\end{tabular}

Vorster submits that of foster care placements, 41 per cent are with the grandmother, 30 per cent with aunts, 12 per cent with other relatives and 9 per cent with non-relatives. ${ }^{54}$

Foster care placement may be with non-family, extended family (kinship care), cluster residential care or even in a $\mathrm{CHH}$. The importance of foster care is well established in international instruments as well as in domestic legislation. ${ }^{5} \mathrm{It}$ is the most frequently used form of formal alternative care for OVCs in South Africa. ${ }^{56}$ Within the formal childcare system, foster care is normally considered to be the preferred form of substitute care for a child who cannot remain with his or her biological family and who is also not available for domestic adoption.

52 Hall and Meintjies "Children Count: Statistics on Children in South Africa Children's Institute" (2011) https://www.childrencount.org.za/indicator.php?id=1\&indicator $=17$ (accessed 2017-08-30) as recorded in the SOCPEN administrative data system of the SASSA.

53 Ibid.

54 Vorster "South Africa: The First Profile of Social Security Grant Beneficiaries" (2007) http://www.africafiles.org/article.asp?ID=16090\&ThisURL=./index.asp\&URLName=HOME (accessed 2017-03-01).

55 Furthermore, the same documents state that children requiring out-of-home care have the right to appropriate alternative care - see Arts 24-25 of the African Charter on the Rights and Welfare of the Child, 1999; s 28(1)(b) of the Constitution; Arts 20(1), (2), (3) and 25 of the CRC.

56 Ibid. 
Prospective foster parents are screened by welfare organisations to ensure they are suitable to take on the responsibility of caring for a child. A children's court summonses prospective foster parents to appear before it pending a foster care order. In this way, the State is involved in the determination of whether or not placement through foster care is appropriate. Two essential elements distinguish foster care from other care. Firstly, foster care consists of care that is provided by the foster care parent or parents - that is, a state institution does not provide the care. Secondly, the act of placement of the OVC in foster care is achieved through a formal process. ${ }^{57}$

Three primary factors require special attention when placing a child in a foster care environment, namely:

1 effective assessment of prospective foster parents by authorities;

2 adequate training of prospective foster parents; ${ }^{58}$ and

3 effective and consistent foster placement support. ${ }^{59}$

Unique to foster care is the characteristic that placement in foster care does not confer "full parental responsibilities" upon the foster parents. In effect, parental responsibilities for the child concerned are shared between the state and the foster parents. ${ }^{60}$ Although it should be noted that foster care is essentially temporary care for the child in his or her community of origin, many foster care placements seem to be developing into long-term placements ${ }^{61}$ as children are rendered orphans, mostly because of the HIV pandemic. ${ }^{62}$ South Africa has the highest rate of AIDS-related deaths in the world, leaving thousands of orphaned and vulnerable children. The reality is that many children placed in foster care do not have the option of returning to the care of their parents. This creates its own set of problems, not least of which are severe financial constraints on the foster caregivers.

Section 186 of the CA makes provision for the relevant court to extend a foster care placement until the child reaches the age of 18 years. This provision effectively removes the requirements of two-yearly social work reports and court reviews. The effect of this provision is an attempt to make foster care a more permanent placement option for a child who cannot live with his or her biological parent or parents.

57 Schäfer Child Law in South Africa: Domestic and International Perspectives 467.

58 Durand The Support and Training of Foster Parents (Masters of Arts dissertation, University of Stellenbosch) 2007 39; Van der Riet Foster Care: The Experiences of Birth Children 7-8 and 27.

59 Booysen Exploring the Causal Factors of Foster Placement Breakdowns (Magister Diaconiologiae dissertation, UNISA) 200636 and 37; Durand The Support and Training of Foster Parents 27; Thiele Exploring the Feasibility of Foster Care as a Primary Permanency Option for Orphans (Masters dissertation, UNISA) 200530.

60 Assim Understanding Kinship Care of Children in Africa: A Family Environment or an Alternative Care Option? 26.

61 Carter A Contextually Appropriate Protocol in Social Work for the Assessment of Prospective Foster Parents in South Africa (MA dissertation, University of Johannesburg) 2013208.

62 Desmond and Kvalsvig Child, Youth and Family Development Evaluating Replacement Childcare Arrangements: Methods for Combining Economic and Child Development Outcome Analyses (2005) 27; Mkhize The Role of Social Worker in Handling of Childheaded Household (Masters dissertation, UNISA) 2006 82; Thiele Exploring the Feasibility of Foster Care as a Primary Permanency Option for Orphans 55. 


\section{1 (ii) Cluster foster care}

Where no related or unrelated foster care parent is available to care for an OVC, the CA provides that a children's court may order that the child be placed in a cluster foster care home. ${ }^{63}$ Section 1 defines a cluster foster scheme as follows:

"a cluster foster care scheme is a scheme managed by a nonprofit organization and registered with the provincial department of social development for this purpose."

This definition has been criticised in that it fails to provide the parameters, contents or contours of what a cluster foster care scheme might be. ${ }^{64}$ One can at least determine that children who are cared for in cluster foster care schemes are cared for by someone who is not a parent or guardian, and who is placed in such care in terms of a court order. ${ }^{65}$ Up to six children may be placed in a cluster foster care scheme, but a scheme may provide care for multiple clusters. ${ }^{66}$ In terms of this form of care, a group of caregivers (duly registered to provide cluster foster care) will, under the supervision of a social worker, care for the children. In light of the HIV/AIDS pandemic, cluster foster care schemes can be viewed as a response from the State to its obligation in terms of section $28(1)(b)$ of the Constitution. ${ }^{67}$ Where institutional and other recognised forms of alternative care are not viable, then appropriate alternative care must be sought for the child concerned. In this respect, section 28(1)(b) is applicable to cluster foster care. The child's care is awarded to the scheme, not the foster parents. The care order does not change if the caregivers change. Section 28(1)(c) also comes under consideration as far as the right to socio-economic rights of the child are concerned. Where there is no family to provide for the child, the obligation falls on the State to provide for the children's rights to shelter, basic nutrition, basic health care services and social services. ${ }^{68}$

Since 2002, the number of orphans in South Africa has risen drastically, and the demand for placement in cluster foster care has increased dramatically. The concerns raised in relation to the management of foster care are equally applicable to cluster foster care. Gallinetti and Sloth-Nielsen note their concern at the process by which a caregiver in a cluster foster care scheme is appointed. In particular, the commentators refer to the basis on which a foster parent is considered qualified, the manner of selection and prior approval of the foster parents. ${ }^{69}$

63 S 156(1)(ii). Likewise, in terms of $S 183$ of the CA, provision is made for groups of children to be placed in the care of a non-profit organisation rather than in foster care.

64 Gallinetti and Sloth-Nielsen "Cluster Foster Care: A Panacea for the Care of Children in an Era of HIV/AIDS or a MCQ?" 2010 46(4) Social Work/Maatskaplike Werk 486-496. The authors opine that $\mathrm{s} 1$ of the CA sheds no further light on what a cluster foster care scheme comprises.

65 S 180(3); Gallinetti and Sloth-Nielsen 2010 46(4) Social Work/Maatskaplike Werk 487.

66 S 185(1).

67 Cluster foster care schemes must be distinguished from unregistered children's homes.

68 Government of the Republic of South Africa v Grootboom 2001 (1) SA 46 (CC) par 19.

69 Sloth-Nielsen and Gallinetti '“Just Say Sorry?' Ubuntu, Africanisation and the Child Justice System in the Child Justice Act 75 of 2008" 2011 14(4) PER/PELJ 492. 


\section{1 (iii) Child-headed households (CHHs)}

As a consequence of the large numbers of children orphaned and the difficulties families face in caring for their relatives who are in need of care, $\mathrm{CHHs}$ have also emerged as a new form of legally recognised alternative care. $^{70}$

For the purposes of this research, a $\mathrm{CHH}^{71}$ is recognised as a household where a child has taken charge of a household in terms of decision-making and responsibility to provide for the physical, social and emotional needs of others living with him or her in that household, regardless of relationship. ${ }^{72}$ Bequele refers to the fact that one of the children in such $\mathrm{CHH}$ heads the household. This child is recognised within the household as being independent and responsible for providing leadership and sustenance for the household concerned. ${ }^{73}$

The children's court has jurisdiction to grant an order to establish a $\mathrm{CHH}$, which consists only of children, with the child-head being 16 years or older. ${ }^{74}$ Recently, CHHs have become a further form of care for children, particularly for those who have lost their parent/s to HIV/AIDS. ${ }^{75}$ An estimated 58,000 children were living in $35,000 \mathrm{CHHs}$ in 2015 . This equates to $0.3 \%$ of all children. ${ }^{76}$

70 Couzens and Zaal "Legal Recognition for Child-headed Households: An Evaluation of the Emerging South African Framework" 2009 17(2) International Journal of Children's Rights 17.

71 Also referred to as a "Child-Only Household" or a "Sibling-Headed Household"; Bequele "Legally Recognising Child-Headed Households" through a Child's Rights Approach Human Development Report 2007/2008 25.

$72 \mathrm{~S} 137(1)(\mathrm{a})$.

73 Bequele "The Emerging Challenges of Children Heading Households: Some Reflections" 2007 The African Child Policy Forum 2.

74 It is accepted that in certain circumstances a terminally ill adult may live with, and be cared for, by the members of the $\mathrm{CHH}$. These instances are excluded for the purpose of this research.

75 A survey undertaken in 2006 indicated that approximately 122000 were living in $\mathrm{CHH}$. During 2013, Social Development Minister, Bathabile Dlamini stated there were 96000 $\mathrm{CHHs}$ in South Africa.

76 Jamieson, Berry and Lake South African Child Gauge 2017 (2017) 99. 


\section{Table 2: Children living in child-headed households, 2002 and $2015^{77}$}

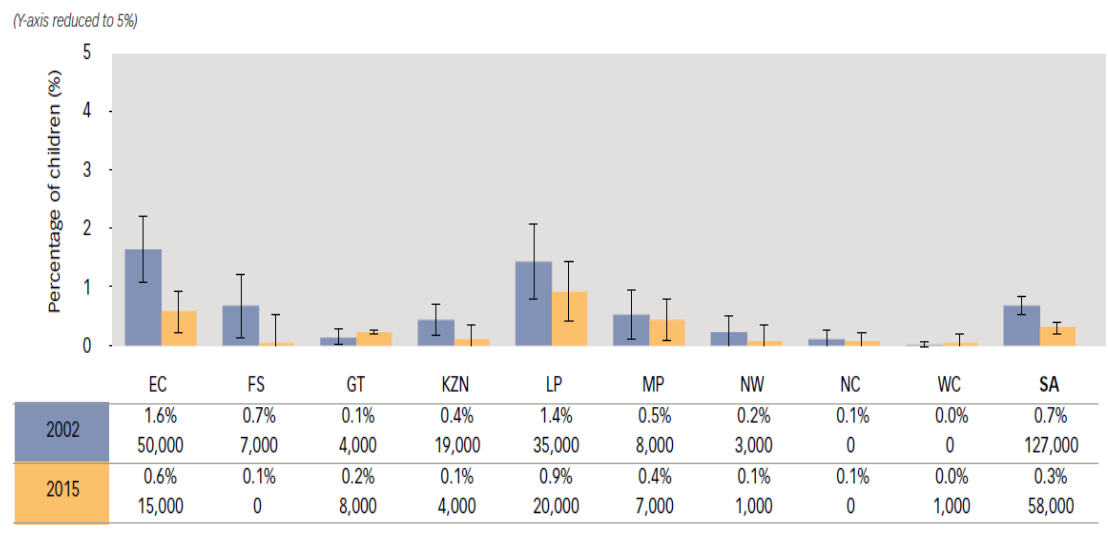

Source: Statistics South Africa (2003; 2016) General Household Survey 2002; General Household Sunvey 2015. Pretoria: Stats SA.

Analysis by Katharine Hall \& Winnie Sambu, Children's Institute, UCT

Considering the figures reflected in Table 2, it is clear that the number of children living in $\mathrm{CHHs}$ has in fact, declined since the figures recorded in 2002. However, 58000 children in $\mathrm{CHHs}$ remains a substantial number of children in such care.

The Table that follows is based on information gathered in 2008 and the statistics reveal where children, who are not in a $\mathrm{CHH}$, are staying. What is obvious is the overall majority of such children reside with their grandmother. The Table below provides reasons as to why children are not living in $\mathrm{CHHs}$. What is evident is that while the number of $\mathrm{CHHs}$ has in fact declined, the reasons for such decline do not necessarily point to a much rosier picture, as the vast majority of children who might otherwise have been living within a $\mathrm{CHH}$ are still not living in a healthy nuclear family.

\section{1(iv) Child and Youth Care Centres (CYCCs)}

A CYCC is defined in the CA as a facility that provides residential care for more than six children who are not living with their biological families. ${ }^{78}$ CYCCs include children's homes, places of safety, secure care centres, schools of industry, reformatories, and shelters for street children. ${ }^{79}$ There are no definite statistics available on the number of CYCCs in South Africa. ${ }^{80}$ Research as published in Public Perceptions, Beliefs and Experiences of

77 Statistics South Africa (2003; 2016) General Household Survey 2002; General Household Survey 2015, Pretoria: Stats SA - Analysis by Hall and Sambu 2016 Children's Institute, University of Cape Town.

78 Since 1 April 2010, and in terms of $s 195$ of the CA, all existing government children's homes, places of safety, secure care facilities, schools of industry or reform schools were classified as CYCCs providing residential care programmes in terms of $s$ 191(2)(a) of the CA.

79 Jamieson Children's Act Guide for Child and Youth Care Workers (2011) 9.

80 Meintjies, van der Walt, Singh, de Preez, de Freitas, Chinnian, Barratt, Govindjee, lya, de Bruin, van Coller Introduction to South African Law: Fresh Perspectives 2ed (2011) 16. 
Fostering and Adoption: A National Qualitative Study in South Africa ${ }^{81}$ provides some data on children who are cared for in CYCCs. However, the report confirms that any data on children in such care is difficult to come by, not least of all given the number of unregistered children's homes that are opening their doors in South Africa. The report indicates that an estimated 15590 children were cared for in CYCCs from 2007. This total is most likely to be an underestimation of the true figures.

A children's court has the jurisdiction to order that a child be placed in a CYCC. In terms of section 159 of the CA, the court may grant such an order for a period of two years, after which time the order lapses. ${ }^{82}$ According to the CA, the placement order cannot extend beyond the child's coming of age. Various circumstances affecting the best interests of the child need to be considered when a court makes an order to place a child in any form of care. Among factors to be considered before placing a child in a CYCC are the child's age and possibilities to place the child within the family. ${ }^{83}$ Residential care is considered as an option only if, and where, no other option is deemed appropriate for the child concerned. This is especially so for those children who are vulnerable to harm because of their circumstances.

If a court decides to place a child in a CYCC, it must take into consideration what specific residential care programme the child concerned needs. Each child should have an individual development plan that describes what programmes and services he or she needs. ${ }^{84} \mathrm{~A}$ court order should then determine that the child be placed at a centre that offers a particular programme that will be of therapeutic value to the child concerned.

\section{Extended family care}

Extended family care (also referred to as kinship care) is an important type of alternative care in South Africa. It is dealt with separately here because it ordinarily offers a vulnerable child a measure of permanence that the other types of alternative care do not.

Historically, the care of children in South Africa was seen as a moral duty or obligation that was binding on all family members. Extended family care is traceable to the African tradition where a child is seen as belonging not just to their nuclear family, but rather that such a child is deemed to fall under the

81 Rochat, Mokomane, Mitchell and The Directorate "Public Perceptions, Beliefs and Experiences of Fostering and Adoption: A National Qualitative Study in South Africa" 2016 30(2) Children and Society 120131.

82 This is so unless the court order indicates that the placement will be for less than two years. The court must review the order every two years and decide to extend the order or release the child.

83 Department of Social Development "South Africa's Child Care and Protection Policy" (2017) https://www.sacssp.co.za/NDSD_CCPP_19_DECEMBER.docx (accessed 2018-04-17).

84 The legal definition of "assessment of a child" to the CA was inserted by s 3 of Act 41/2007 as follows: "[A]ssessment of a child means a process of investigating the developmental needs of a child, including his or her family environment or any other circumstances that may have a bearing on the child's need for protection and therapeutic services." 
responsibility of the entire community within which they are born. ${ }^{85}$ Almost all orphans lived with relatives. ${ }^{86}$ Kinship care of orphaned and abandoned children is valuable in a number of ways inter alia in that it gives effect to the child's constitutional right to either parental or family care and it also contributes significantly to their well-being, development and protection. ${ }^{87}$ The majority are in "informal kinship care", with a smaller proportion having been formally placed by the courts into statutory foster care with relatives. ${ }^{88}$ Assim refers to the fact that kinship care is not necessarily restricted to biological or genetic ties. ${ }^{89}$ Ezewu defines kinship care as follows:

"From actual practices in the various societies in Africa, the following characteristics can be observed:

1 The extended family system is a combination of several nuclear, polygamous, or polyandrous types of family, and the relationships between the members are biological and social.

2 The members through biological relationships usually trace their origin to a common ancestor, lineage and a common genealogical line.

3 The members usually occupy a specific geographical location in a village or city as a home place for all members even if they live in other parts of the world, returning to it from time to time.

4 The members have a common identity and group feelings, looking up to one another for help at times of disaster or misfortune and sharing one another's happiness." 90

However, it does not mean that extended family care is always considered by the children concerned to be the best option for them. Mathebula states that following a survey of children living in $\mathrm{CHHs}$, some of the children indicated that the extended families did not play a vital role in their lives while the parents were still alive, and as such, these children regarded the extended family with suspicion about wanting to use them for financial gain such as receiving the FCG. ${ }^{91}$ What is significant is the way in which different cultures give social meaning to ties that may be understood as biological, and are thus deemed to be kinship ties. ${ }^{92}$ Extended families often provide the first and, debatably, the most important form of informal care in South Africa and such care should not be ignored. Kinship care can serve as a

85 Assim In the Best Interest of Children Deprived of a Family Environment: A Focus on Islamic Kafalah as an Alternative Care Option (LLM dissertation, University of Pretoria) 2009 22-23.

86 Office of the United Nations High Commissioner for Human Rights "Country Fact Sheet for the CRC" http://tbinternet.ohchr.org/Treaties/CRC/Shared\%20Documents/ZAF/INT_CRC_ NGO_ZAF_22832_E.pdf (accessed 2017-07-23).

87 Department of Social Development https://www.sacssp.co.za/NDSD_CCPP_19 DECEMBER.docx.

88 Khomba Redesigning the Balanced Scorecard Model: An African Perspective (PHD thesis, University of Pretoria) 2011130.

89 Assim Understanding Kinship Care of Children in Africa: A Family Environment or an Alternative Care Option? 17.

90 Ezewu "The Relative Contribution of the Extended Family System to Schooling in Nigeria" 198655 The Journal of Negro Education 222.

91 Mathebula From being in Charge of a Child-Headed Household to being Placed in Kinship Foster Care: The Experiences and Expectations of Orphans Previously in Charge of ChildHeaded Households (Master of Arts in Social Science dissertation, UNISA) 20126.

92 McCarthy and Edwards Key Concepts in Family Studies (2011) 128. Refer to the acceptance that ties with unrelated individuals may be described as "fictive kinship" or "quasi kinship". 
means to ease the pain of children who have lost one or both birth parents and tends to provide familial and cultural continuity.

While neither the Convention on the Rights of the Child (CRC) nor the African Charter on the Rights and Welfare of the Child (ACRWC) makes any direct reference to kinship care as an accepted form of alternative care, the United Nations Guidelines for the Alternative Care of Children does make direct reference to it. ${ }^{93}$ The United Nations Guidelines are significant because not only is provision made for the express recognition of kinship care as a form of alternative care; it was also as a consequence of the practice of kinship care that the United Nations was motivated to draft the Guidelines ${ }^{94}$ Care by the extended family plays a vital role in providing care for many abandoned and orphaned children in South Africa. For the most part, this form of alternative care plays a positive role in the abandoned or orphaned child's life, inter alia by ensuring stability in the child's life and the opportunity to be cared for by family where the biological parents are unable or unwilling to care for the child concerned. Within the system of alternative care, care by the extended family is generally seen as the first option of placement in South Africa for vulnerable children.

Characteristically, within the extended family system, great reliance is placed on women, particularly on the grandmother/s of the OVC to provide the care needed. As can be expected, the situation inevitably leads to further costs for the caregiver. Considering the de facto financial position of elderly women especially, it is evident that they will often need access to financial support. The recent court judgment allowing grandparents who provide such care to access an FCG has provided some relief in this regard. ${ }^{95}$ Generally, only where it is impossible for the extended family to care for an OVC do children become the responsibility of unrelated caretakers. However, the extent of HIV/AIDS in South Africa has resulted in a large-scale breakdown in this well established traditional structure of care, leading to a decrease in the capacity of extended family members to provide such care. ${ }^{96}$ Furthermore, there has been a noticeable decline in the number of prime age caregivers, such as aunts and uncles. Mathebula opines that this decline of caregivers in their prime age "implies that relatives, who took over the responsibility for taking care of orphan children, are also ill and dying due to the HIVIAIDS pandemic". 97

The number of children who are placed with extended family far exceeds the estimate of orphans who have lost both parents in South Africa. This can be accounted for because factors may drive child placement in relatives' homes such as migratory work, the location of a secondary or better schooling, the inability of parents to provide for their children, and illness. ${ }^{98}$

93 Guidelines for the Alternative Care of Children, GA Res 64/142, UN Doc A/RES/64/142, 64 ${ }^{\text {th }}$ Session (2009).

94 UN Guidelines par 29(b)(i) and (c)(i).

95 SS v Presiding Officer, Children's Court, Krugersdorp 2012 (6) SA 45 (GSJ).

96 Gallinetti and Sloth-Nielsen 2010 46(4) Social Work/Maatskaplike Werk 486.

97 Mathebula From being in Charge of a Child-Headed Household to being Placed in Kinship Foster Care: The Experiences and Expectations of Orphans Previously in Charge of ChildHeaded Households 6.

98 UNICEF Alternative Care for Children in Southern Africa: Progress, Challenges and Future Directions (2008) 3-4. 
Determining the number of children who stay within the extended family is very difficult, and no reliable statistics are available. However, statistics are available on carers who are entitled to a child support grant. The majority of children placed in extended family care are placed informally. ${ }^{99}$ South Africa has more than 1.2 million maternal orphans and the vast majority of them are cared for by family members. ${ }^{100}$ According to International Social Service (ISS) Country Fact Sheet for the CRC, in 2011 South Africa had approximately 1.5 million maternal and double orphans.

From the figure below, one can deduce that in 2014 some 3868000 children lived with relatives other than their biological mother and/or father. ${ }^{101}$ This provides an approximation of the number of children living in extended care in 2014 and when compared to the statistics provided by ISS in 2011, it is evident that there has been a significant increase in the number of children living in extended family care.

\section{Figure 1: Children in co-residence arrangements $2014^{102}$}

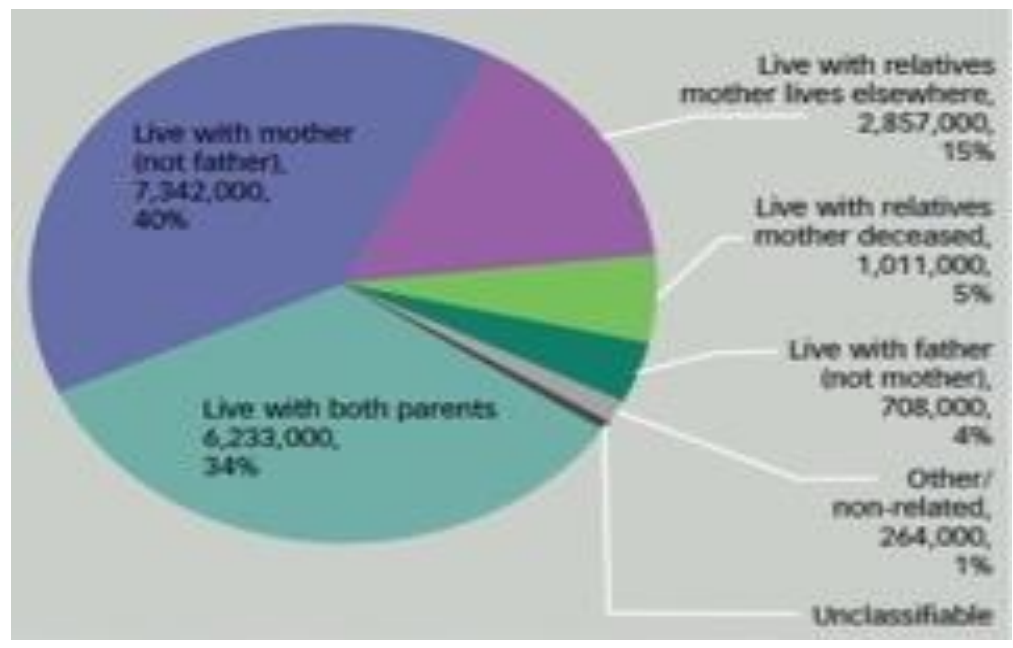

In SS v Presiding Officer, Children's Court, Krugersdorp, ${ }^{103}$ the court considered the instance where aunts and uncles took care of their nephews and nieces. The question before the court was whether these nephews and nieces could be considered to be children in need of care as envisaged in

99 The researcher telephoned Ms Lori Lake at Child Gauge in an attempt to determine the number of children living within the Extended Family System in South Africa at present. It was indicated that such statistics are not available and very difficult to determine accurately. According to Proudlock South Africa's Progress in Realising Children's Rights: A Law Review (2011), South Africa had approximately 1.5 million maternal and double orphans. The overall majority of these orphaned children lived with relatives, with "informal kinship care" being the most frequently found. A smaller proportion of orphaned children in South Africa are formally placed by the courts into statutory foster care with relatives.

100 Delany, Jehoma and Lake South African Child Gauge (2016) 16.

101 Statistics South Africa "General Household Survey" http://www.statssa.gov.za/publications/ P0318/P03182014.pdf (accessed 2017-05-20).

102 Delany, Jehoma and Lake South African Child Gauge 35.

103 Supra. 
terms of the CA. The lower court's refusal to find such children to be in need of care was overturned on appeal. In making its judgment, the Appeal Court held that since the aunts and uncles owed their nephews and nieces no common law duty of support in South African law, as carers for the children they were entitled to receive a social grant to assist financially in caring for the children concerned. An unfortunate consequence of this judgment lay in the fact that grandparents, who do at common law owe their grandchildren a duty of support, were excluded from receiving any form of social assistance when caring for their grandchildren.

The subsequent order of the South Gauteng High Court in NM v Presiding Officer of Children's Court, Krugersdorp ${ }^{104}$ has accordingly been hailed as a positive development. It has clarified the meaning of section 150(1)(a) of the $\mathrm{CA}$ and makes it clear that a caregiver who bears a common law legal duty of support (like a grandparent) may qualify to be a foster parent, and as such may be entitled to receive an FCG. Legal Aid SA welcomed the court ruling, stating that the spirit of the CA had been realised, in that orphaned children would no longer have to be separated from their families to qualify for an FCG.

The court furthermore provided guidelines for children's courts to follow when interpreting section 150(1)(a). These include how to determine whether a child is in need of care, and thereafter whether the child has a visible means of support. It was emphasised that the focus needed to be on whether the children had a visible means of support and not on whether the caregiver had a visible means of support. The children's court had for some time misinterpreted "visible means of support"105 in the determination of whether a child was "in need of care and protection" as provided for in section 150(1)(a) of the CA. As a result, some parents and relatives were held not to qualify for an FCG and foster care order in respect of children related to them as they were considered to owe such children a common law duty of support. Since the court now found that the means to be taken into account was that of the child, a prospective foster parent who owes a child a common law duty of support is no longer precluded from receiving an FCG in respect of such a child.

The difference in the amount received by a caregiver who receives an FCG and one who is entitled only to a CSG is substantial. The South African Child Gauge reports that in 2016 the value of a CSG was R380 per month, with 11972900 children being recipients of such grants at October 2016. In the same year, 470000 children were in receipt of an FCG. In 2017, over 12 million children received social grants. ${ }^{106}$ The amount of the FCG is

1042013 (4) SA 379 (GSJ).

105 See Department of Social Development "Children's Act: Implementation Challenges and Proposed Amendments: by Departments of Social Development and Justice and Constitutional Development" (2013) (https://pmg.org.za/committee-meeting/16173) for an overview of the problems faced when interpreting s 150(1)(a) of the CA.

106 Children Count "Current Statistics on Grants for Children" (undated) http://www.childrencount.org.za/ (accessed 2017-04-04). See also Children Count "Statistics on Children in South Africa" (undated) http:// www.childrencount.org.za/ (accessed on 2017-06-06). 
restricted to a maximum of six children per household. ${ }^{107}$ Following the Budget speech delivered by ex-Minister Pravin Gordhan in February 2017, FCGs increased by R30 to R920 a month, and the CSG by R20 to R380 a month. ${ }^{108}$ This is the amount that foster care parents are paid in 2018. The awarding of an FCG forms part of the statutory obligation of the State to provide care and protection for those in need. Although a potential difficulty lies in the sustainability of grants, Hall says the outcomes to date have been positive:

"The effects of the grant have been shown in multiple studies, and are widely known: children who receive grants, or even those who live in households where others receive grants, have better health and nutritional outcomes when controlling for other variables, and they do better at school. Grants are also associated with less risky behaviour among teenagers." 109

However, the protection of these rights and principles has unfortunately often been perverted. Driven by factors that include inter alia poverty, health, and social and economic factors, it is not surprising that poverty-stricken families resort to reliance on FCGs to alleviate such poverty. ${ }^{110}$ The difference between the amounts granted in terms of a CSG versus that of a FCG ${ }^{111}$ has created an incentive for the communities to opt for the FCG. ${ }^{112}$ A "means test" is required to determine who qualifies for a CSG, and the grant is awarded to the primary caregiver of a child in need of financial assistance. For example, a parent, grandparent or a child over 16 years of age heading a $\mathrm{CHH}$ can apply and be granted a CSG. ${ }^{113}$ Albeit only to grandparents, this extension acts as an olive branch to a family member to keep the child within the family environment. This is not without its problems, and these are discussed later in this article. It is also telling that no grant is awarded when a child is adopted. Blackie reports that FCGs increased by 70

107 Kelly and GroundUpStaff "Everything you Need to Know about Social Grants: For People who Receive a Grant or Need to Receive One (2017) https://www.groundup.org.za/ article/everything-you-need-know-about-social-grants_820/ (not paginated) (accessed 2018-07-29); Madsaparent 24 "How to get Child Support Grants in South Africa" 2018 (not paginated) https://www.parent24.com/Family/Finance_Legal/Child-support-grants-in-SouthAfrica-20150826.

108 Merten "In Numbers: Budget" (10 July 2017) https://www.dailymaverick.co.za/article/201702-22-in-numbers-budget-2017/\#.WtnO2lhuZPY (accessed 2017-04-04).

109 Office of the United Nations High Commissioner for Human Rights http://tbinternet.ohchr. org/Treaties/CRC/Shared\%20Documents/ZAF/INT_CRC_NGO_ZAF_22832_E.pdf.

110 A social grant, such as a foster care or a child support grant, refers to a grant paid by the South African Social Security Agency.

111 Children's Institute, University of Cape Town reports that 11.97 million children were receiving the CSG in 2016. In the same year, 470000 children were in receipt of a FCG. In 2017, over 12 million children receive social grants. Children's Institute, University of Cape Town "Current statistics on grants for children" (2017) http://www.childrencount.org.za (accessed 2017-04-04).

112 SASSA "You and Your Grants 2016/2017" (2017) http://www.sassa.gov.za/index.php/knowledge-centre/grant-booklets?download=523:youand-your-grants-2016-2017\&start=6 (accessed 2017-03-04).

113 Only people whose income is below a certain level qualify for the grant. In order to qualify, the Social Assistance Act 13 of 2004 provides that a person may not earn more than R42 000 per year if single. If married, the caregiver's combined income should not be more than R84 000 per year. 
per cent between 2013 and 2014,,$^{114}$ while adoption decreased by 30 per cent over the same period. ${ }^{115}$

The proposed amendment of the CA in order to provide clarity on the test used to determine a child's eligibility to be placed under foster care has as yet not been effected. The proposed amendment of section 150(1)(a) of the CA would replace the words "is without any visible means of support" with the words "does not have the ability to support him- or herself and such inability is readily evident, obvious or apparent". ${ }^{116}$ Such an amendment would bring the section in line with the South Gauteng High Court judgment in NM v Presiding Officer of the Children's Court, District of Krugersdorp ${ }^{117}$ and also clarify the provision of this section.

The confusion surrounding the eligibility of grandparents to receive FCGs has finally been clarified. In April 2013, the South Gauteng High Court in Manana $v$ the Minister of Social Development ${ }^{118}$ decided that in determining "visible means of support", account should not be taken of the means of a prospective foster parent even if the foster parent is related to the child; the "means" to be taken into account is that of the child.

In essence, the ruling clarifies the fact that orphaned children under the care of grandparents do qualify for FCGs, subject to a financial inquiry being conducted on the caregivers having a common law duty of support. ${ }^{119}$

While the judgment is a step in the right direction, the judgment does not provide a solution to the backlogs in the foster care system caused by a lack of capacity of social workers and courts to keep up with the numbers in need. Proudlock has stated:

Unfortunately, the judgment does not solve the systemic problems that still exist, and may in all likelihood add to the pressure on the foster care system, as it opens the doors for more people to be placed on an already stretched system. ${ }^{120}$

\section{Challenges and concerns in implementing alternative care in South Africa}

A consideration of the concerns with the existing impermanent alternative care options in present-day South Africa follows.

114 Blackie Sad, Bad and Mad: Exploring Child Abandonment in South Africa 18.

115 Blackie Sad, Bad and Mad: Exploring Child Abandonment in South Africa 9.

116 Children's Institute University of Cape Town (2015) http://pmg-assets.s3-website-eu-west1.amazon laws.com/150904Childrens_Institutesubmission.pdf 3 (accessed 2018-04-24).

117 (A3075/2011) [2013] ZAGPJHC 64; 2013 (4) SA 3979 (GSJ); [2013] 3 All SA 471 (GSJ) (12 April 2013).

118 Case Number A3075/2011.

119 Legal Aid South Africa "South Gauteng High Court Ruling on Foster Care Grants makes the Child Justice Act 38 of 2005 a Reality for Orphaned Children" (16 April 2013) http://www.legal-aid.co.za/wp-content/uploads/2012/03/2013-16-April-_Ruling-on-fostercare-grants-helps-orphaned-children.pdf 2 (accessed 2017-04-04).

120 Children's Institute University of Cape Town "UCT Institute Supports Foster Child Grant" (2013) https://www.news.uct.ac.za/article/-2013-04-29-uct-institute-supports-foster-childgrant-campaign (accessed 2017-06-24) 


\section{5 (i) Concerns with foster care placement}

Placing children in foster care in South Africa gives rise to many concerns. The most serious concerns stem from the strain that the welfare system is under as a result of the huge numbers of children placed in foster care fueled especially by the HIV/AIDS pandemic. Freeman and Nkomo are among commentators ${ }^{121}$ who have noted with concern that, as the HIV/AIDS pandemic increases, so the services and structures in place to ensure the care of vulnerable children become increasingly strained and overwhelmed. ${ }^{122}$ Included here is the strain placed on the extended family to take care of orphaned or vulnerable child relatives.

The DSD is under stress as it struggles to keep up with the demand for foster care placement applications. The Centre for Child Law, Legal Aid SA, the Black Sash and the Children's Institute are concerned that the foster care system is failing to assist family members caring for orphaned children. ${ }^{123}$ Besides failing orphans, the system is also failing abused and neglected children who desperately need the services of the overwhelmed social workers and children's courts. The foster care system was designed to accommodate 50000 children, yet it now has over 500000 children to care for. ${ }^{124}$

The duties of social workers increased with the enactment of the CA although they were already struggling to keep up with their workload. Although the CA aims to ensure the protection of children's rights and ensure that informed decisions be made in their best interests, the number of social workers employed by the DSD is wholly inadequate to keep up with the constant and increasing demands they face.

Section 158 of the CA requires that a foster care order be reviewed by the children's court every two years (unless the court has specified a shorter period). The predecessor of the CA, the Child Care Act, ${ }^{125}$ made no such provision. ${ }^{126}$ The review requirement has further burdened already overburdened social workers ${ }^{127}$ and has also had considerable budgetary implications. By 2010, as a result of social workers being unable to keep up with their administrative duties, which include initial investigations and reports by social workers, court-ordered placements, and additional twoyearly social worker reviews and court-ordered extensions, thousands of foster care orders had begun to lapse, meaning that the children concerned

121 Freeman and Komo "Guardian of Orphans and Vulnerable Children: A Survey of Current and Prospective Care Givers" 2006 18(4) Journal of AIDS Care 302-310; Roux, Bungane and Strydom "Circumstances of Foster Children and their Foster Parents Affected by HIVIAIDS" 2010 46(1) Social Work/Maatskaplike Werk 45; National Academy of Sciences Preparing for the Future of HIVIAIDS in Africa: A Shared Responsibility: The Burden of HIVIAIDS: Implications for African States and Societies (2011) 25.

122 Ibid.

123 See IOL "Huge Relief for Orphans and Grandparents" (2013) https://www.iol.co.za/pretorianews/opinion/huge-relief-for-orphans-and-grandparents-1505114 (accessed 2017-09-25).

124 Ibid.

125 Child Care Act 74 of 1983.

126 In terms of the Child Care Act, foster care orders were reviewed administratively by the Department of Social Development (DSD).

127 Breen http://children.pan.org.za/sites/default/files/publicationdocuments/Child\%20Welfare \%20Policy\%20Brief-\%20 Foster\%20Care\%20March\%202015.pdf 5. 
were no longer legally placed in foster care, and nor were they eligible for the FCG. ${ }^{128}$ Owing to the backlogs, over 110000 foster care orders had lapsed and children had lost their income support, creating hardship and tragedy.

In 2011, after ChildLine and Child Welfare sought its help, the Centre for Child Law ${ }^{129}$ brought an urgent court application ${ }^{130}$ for interim relief, in an attempt to avoid a crash of the system. The court ordered that all lapsed FCGs were deemed not to have lapsed and that these foster care orders, together with the FCGs, could be extended administratively until the DSD could provide a solution to the problem. ${ }^{131}$ The court order provided temporary alleviation of the pressure on the foster care system. The backlogs stem from a lack of resources to deal with the high numbers of foster care orders, including overcrowded court rolls and overburdened social workers. An inter-ministerial task team was established and tasked to address the challenges experienced in the foster care system. In spite of these efforts, the court order expired in December 2014 before the team could find a solution.

At this time, and in the wake of another potential crisis, the DSD approached the court requesting an extension to 2017 or until such time as the CA could be amended. ${ }^{132}$ The order was granted, stipulating that lapsed orders were deemed not to have lapsed and to be valid for a further period of two years. ${ }^{133}$ The Centre for Child Law recommended that the DSD be compelled to report to the court every six months on the progress they had made in solving the current, and potentially future, backlog of cases. This recommendation was accepted and made part of the court order. Skelton stated, "the purpose of granting the Department of Social Development breathing space was to allow the department to develop a solution to solve the systemic problems in the foster care system". ${ }^{134}$

Furthermore, a report undertaken by the Children's Institute in 2018 shows that the FCG is not reaching the majority of orphans in need thereof. ${ }^{135}$ It had taken the DSD many years to reach those orphans who are

128 Hall and Meintjies https://www.childrencount.org.za/indicator.php?id=1\&indicator=17 (accessed 2017-08-30) as recorded in the SOCPEN administrative data system of the SASSA.

129 Ibid.

130 S v J[2011] 2 All SA 299 (SCA); 2011 (3) SA 126 (SCA).

131 lbid.

132 Case Number 21726/11.

133 Fortune An Overview of the Foster Care Crisis in South Africa and its Effect on the Best Interests of the Child Principle: A Socio-Economic Perspective (research paper, University of the Western Cape) 2016 9; Davis "Festering Indifference: Foster Care Grant Mess has Echoes of SASSA Crisis" (2017) Daily Maverick (not paginated) https://www. dailymaverick.co.za/article/2017-03-21-festering-indifference-foster-care-grantmess-has-echoes-of-sassa-crisis/ (accessed 2018-07-27).

134 Skelton "1 Million Orphans Need the Foster Child Grant: Over One Million Orphans Desperately Need the Foster Child Grant - Can the Department of Social Development deliver?" (2013) Health24 (not paginated) https://www.health24.com/Parenting/Child/News/ 1-million-orphans-need-the-foster-child-grant-20130417 (accessed 2018-07-27).

135 Röhrs, Proudlock and Maistry "Legislative and Policy Developments 2016/2017" 2017 South African Child Gauge 12-17 http://www.ci.uct.ac.za/sites/default/files/image_tool/ images/367/Child_Gauge/South_African_Child_Gauge_2017/Child_Gauge_2017-

Legislative_developments_in_2016-2017 (accessed 2018-08-30); Hall, Skelton and 
fortunate enough to receive such grants. ${ }^{136} \mathrm{Xi}$ reported in 2014 "[O]ver a million orphans and abused, neglected, and abandoned children in South Africa are falling through the cracks of an overburdened foster care system". ${ }^{137}$ The existing system is clearly not in a position to accommodate or afford the payment of the FCG for more children: grants are lapsing because the system is not able to keep up with the vast numbers of fostered children. ${ }^{138}$ The FCG was originally mainly used as child protection support for children who were placed in foster care in terms of a court order because of the abuse, neglect or abandonment they had experienced. For social workers, the process involves home visits and interviews with the child's family, writing a court report, obtaining approval by a supervisor, and getting a court date. This requires that the social workers concerned must conduct new investigations and submit new reports. Failing this, the FCG lapses.

Owing to their workload, social workers seldom have time to adequately assess the foster parents, leading to the potential that such placement might well breakdown, which is detrimental to the well-being and sense of security for the child concerned. Carter opines that social workers further lack the experience to assess the foster parents adding as follows:

Most universities in South Africa address foster care in a section of a semester module on the continuum of care (according to verbal reports from discussions with heads of seven social work departments at South African universities, or lecturers there, from 2008 to 2014). Given the scope of the continuum of care, foster care is touched on only briefly. Given the complexities of foster care, it appears that current social work students are not adequately prepared by universities to deal with foster care in the field. ${ }^{139}$

Likewise, social workers struggle to find the time, given their overburdened workload, to physically getting around seeing a foster child, and for the same reason, the foster parent. The average visit to a foster care home is at present only once a year. ${ }^{140}$ This is not satisfactory given the impact that placement in alternative care has on a particular child. Carter refers to three primary factors that appear to have a positive impact on foster placement namely the stability of the child achieved through the effective screening and assessment of prospective foster parents; the provision of adequate training of prospective foster parents; and finally, foster placement support. ${ }^{141}$ As indicated, this is not taking place in South Africa. The Table

Sibanda "Social Assistance for Orphaned Children Living With Family" 2016 South African Child Gauge 69-70.

136 Skelton https://www.health24.com/Parenting/Child/News/1-million-orphans-need-the-fosterchild-grant-20130417 (accessed 2018-07-27). In this article, regard is had to the struggle that orphans seeking a grant have faced since 2002. At the time, the number of orphans was steadily increasing as a consequence of the HIV pandemic.

137 Media Release "The foster care system is failing a million orphans: Child rights NGOs call for a kinship grant" (2015) http://www.ci.uct.ac.za/sites/default/files/image_tool/images/367/ Projects/Current_Projects/Civil\%20Society\%20Briefing\%20on\%20Foster\%20Care\%20May \%202015.pdf (accessed 2018-07-27).

138 Hall "Children Count Statistics on Children in South Africa" (2017) http://childrencount.uct.ac.za/indicator.php?domain=1\&indicator=1\#6/-28.692/24.698 (not paginated) (accessed 2018-08-08), indicates that 12273900 CSGs were paid out by SASSA at the end of March 2018, and that 416016 FCGs were disbursed.

139 Carter and Van Breda 2016 52(2) Social Work/Maatskaplike Werk 211.

140 Roux, Bungane and Strydom 2010 46(1) Social Work/Maatskaplike Werk 51.

141 Carter and Van Breda 2016 52(2) Social Work/Maatskaplike Werk 211. 
below provides some insight into the contact or lack thereof that social workers have on average with children placed in foster care.

\section{Table 3: Contact with a social worker ${ }^{142}$}

\begin{tabular}{|l|l|l|l|l|l|}
\hline $\begin{array}{c}\text { Frequency of } \\
\text { contact with } \\
\text { foster children }\end{array}$ & \multicolumn{1}{|c|}{} & \multicolumn{1}{|c|}{$\%$} & $\begin{array}{c}\text { Frequency of } \\
\text { contact with } \\
\text { foster parents }\end{array}$ & $\mathbf{F}$ & \multicolumn{1}{|c|}{} \\
\hline Once a week & 1 & 4,76 & Twice a month & 1 & 4,76 \\
\hline Once a year & 14 & 66,67 & Once a year & 12 & 57,14 \\
\hline Once in two years & 3 & 14,29 & Once in two years & 7 & 33,33 \\
\hline Do not know & 2 & 9,53 & Never & 1 & 4,76 \\
\hline Never & 1 & 4,76 & & 0 & 0 \\
\hline $\mathbf{N}$ & $\mathbf{2 1}$ & $\mathbf{1 0 0}$ & $\mathbf{N}$ & $\mathbf{2 1}$ & $\mathbf{1 0 0}$ \\
\hline
\end{tabular}

Both foster children and foster parents indicate that they do not receive individual or group therapy that would be of assistance to both child and foster parent in building and strengthening personal relations between the foster child and foster parent. Despite a shortage of social workers to fulfil these duties, social workers nonetheless have a responsibility to their clients (the foster child and foster parent) and to the community. The situation is clearly untenable.

Foster parents should be carefully screened to determine their ability to provide good care to children. ${ }^{143}$ Carter and Van Breda note their concern at the screening processes for foster care placements, and especially with the fact that there is no set of objectives and contextually relevant criteria to guide the assessment of prospective foster parents. ${ }^{144}$ Without standardised data for use by the social workers involved, there is no potential for the development of national standards that would be of great assistance in best monitoring the well-being of foster children. While the CA makes provision for broad assessment criteria, the CA leaves the interpretation of these criteria up to the social workers involved.

It is submitted that among the reasons for the inadequate screening of foster parents by social workers is a lack of knowledge by social workers on how to assess prospective foster parents. Most universities in South Africa address the system of foster care only in part of a one-semester module of a degree in Social Welfare. Foster care is thus touched on only very briefly. Following discussions with members of seven social work departments at South African universities from 2008 to 2014, Van Breda and Carter refer to

142 Bungane Guidelines for Social Workers to Improve Foster Care Placements for Children affected by HIV/AIDS (Magister Artium (Social Work) dissertation, Potchefstroom Campus of the North West University) 200719.

143 When a foster placement is inadequately assessed (whether for family-related foster care or unrelated foster care), there is an increased likelihood that that placement itself could be unsuccessful and culminate in the breakdown of care. These instances are detrimental to the child's well-being. There are various reasons cited for such breakdowns, including the movement of the foster child into adolescence; the complexity of the child's social problems; a lack of foster parent support; the incorrect matching of a child to the foster parent; interference from the biological family and the over-burdening of social service systems.

144 Carter and Van Breda 2016 52(2) Social Work/Maatskaplike Werk 226. 
this inadequacy at the tertiary education level. It appears that current social work students are not adequately prepared by universities to deal with the complexities of foster care in the field. ${ }^{145}$

The DSD has developed new foster care guidelines - namely, "Guidelines for the Effective Management of Foster Care in South Africa". ${ }^{146}$ However, these guidelines fail to explain how to assess a prospective foster parent and instead provide a detailed explanation of the statutory process of foster care in South Africa. Social workers in South Africa screen potential foster parents without any clear guidelines from the government, which is further compounded by their lack of adequate training at a tertiary level. The assessment of prospective foster parents should be essentially an extensive information-gathering exercise and evaluation of the ability and suitability of the prospective foster parent with the aim to ensure a safe, stable, loving and nurturing environment for foster children. ${ }^{147}$ For several reasons, the evaluation should take place against a set of objective criteria. These include the fact that foster care orders may be extended for more than two years, ${ }^{148}$ and an effective assessment enhances placement stability.

Many children placed in foster care have a greater potential to manifest behavioural and emotional problems. ${ }^{149}$ Many come from broken and dysfunctional families, and it is of the utmost importance that supportive training be offered to foster parents to empower and capacitate them to best look after the child concerned. ${ }^{150}$ The intention of the legislator was to design a social technology innovation that social workers would be able to use for the assessment of prospective foster parents. Without this in place, Perumel and Kasiram express the view that placement of a child in a CYCC that has a therapeutic programme in place may, in fact, be more suitable for serving the best interests of the child than foster care. ${ }^{151}$ The greatest advantage of institutional care is its ability to ensure that children have access to vital services identified as essential by the authorities concerned. However, deep concerns remain concerning the placement of a child in a CYCC.

Too few of the parties involved in foster placement, including the foster parents, have sufficient, or any, training regarding the actual fostering of a child. This renders them inadequate to deal effectively with potential crises or problems that may arise. Social workers battle to place children given the absence of an appropriate protocol for assessing prospective foster parents and they are in need of additional support and resources to assess prospective foster parents.

While foster care provides a child with substitute parents (in a loose sense), it is care that is temporary in nature and this can have a negative

145 Carter A Contextually Appropriate Protocol in Social Work for the Assessment of Prospective Foster Parents in South Africa 6.

146 Carter and Van Breda 2016 52(2) Social Work/Maatskaplike Werk 210.

147 Give a Child a Family is an organisation that was established in 1992.

$148 \mathrm{~S} 186$ of the CA.

149 Waid, Kathari, Bank and MacBeath "Foster Care Placement Change: The Role of Family Dynamics and Household Composition" 2016 Child Youth Serv Rev 68.

150 Perumal and Kasiram 2008 44(2) Social Work/Maatskaplike Werk 165.

151 Ibid. 
impact on a child's psychological well-being and mental development. ${ }^{152}$ This is all the more prominent in cases of so-called "foster drift", in which children experience placement with several foster families without securing permanence. Children's developmental needs change as they grow. Where a social worker has contact on average once a year with a child placed in foster care, and equally on average once a year with the foster parent (who is not receiving appropriate training), it is submitted that the changing needs of the child and his or her best interests are unlikely to be well served.

Once an OVC reaches the age of majority (18 years) and leaves formal care, no support is provided to assist such a child. This represents a further negative for a foster child who at the age of majority finds him- or herself out of the network of security that a family environment naturally provides.

Given the stresses of an overburdened work environment, there is also an unsurprisingly high turnover in the employment of social workers. One can easily predict the negative impact this may have on a child in foster care who has built up a relationship of trust with the social worker concerned with the placement. Despite severe failings in the current foster care system in South Africa, the government has failed to address the problems, and no sustainable solution has been suggested. The foster care system is fraught with uncertainty, potential instability and a lack of permanence for the child concerned. Social workers themselves raise disconcerting concerns about the efficacy of the foster care service they render. ${ }^{153}$ Many criticise the current system, saying that it creates an incentive for impoverished families to place their children in the foster care of others in order to achieve financial relief. The criticism is founded on the approach that the State fails to provide adequate support for all vulnerable families. OVCs have been rendered more vulnerable than ever despite a constitutional imperative that these children deserve the best service and commitment that the social welfare services have to offer.

It is submitted that the DSD needs to re-think its way of operating. The CA has created further obligations for social workers and the judiciary, and social workers are not able to give the attention required for individual foster placements. In September 2012, the DSD announced its intention to introduce reform aimed at providing a grant that relatives could access directly via an application to the South African Social Security Agency (SASSA). ${ }^{154}$ This would cut out the need for a social worker report and a court inquiry, thereby ensuring that all entitled orphans would have a quicker response and access to a grant. ${ }^{155}$

152 Assim Understanding Kinship Care of Children in Africa: A Family Environment or an Alternative Care Option? 121.

153 Carter and Van Breda 2016 52(2) Social Work/Maatskaplike Werk 210.

154 Black Sash Media Statements "Over One Million Orphans Desperately Need the Foster Child Grant - Can the Department of Social Development Deliver?" (2013) https://www. blacksash.org.za/index.php/media-and-publications/media-statements/282-black-sashmedia-statement-over-one-million-orphans-desperately-need-the-foster-child-grant-can-thedepartment-of-social-development-deliver-18-april-2013 (not paginated) (accessed 201808-08).

155 Simula Developing an Evidence-Based Foster Mother Screening Tool For Cluster Foster Care In The Western Cape, South Africa (MSocSc in Clinical Social Work dissertation, University of Cape Town) 201657. 


\section{5 (ii) Concerns about cluster foster care}

Concerns about cluster foster care are acknowledged. Simula opines that following interviews done with the cluster foster care "mothers" the following concerns were raised:

"Foster care mothers require training as they as a general rule care for children who come from traumatic backgrounds. Such training would equip the caregivers with behaviour management skills so that they are able to deal with the varied behavioral traits of the children in cluster foster care."156

Furthermore, where a cluster foster caregiver has not been adequately trained, they are less likely to remain in service as a caregiver. ${ }^{157}$ The turnover of caregivers has a negative psychological effect on the foster children they care for. Financial constraints are also cited as a concern. Simula refers to a participant in her research where such foster-carer reported that the state grant was not enough to cover all the foster child's needs. As a consequence, carers might have to resort to using their own salary to what is needed by the children in their care. ${ }^{158}$

\section{5 (iii) Concerns with Child and Youth Care Centre's}

Mudaley opines, "the child in the Children's Home comes from a lifeworld of lack of appreciation, neglect, inadequate and destructive relationships, impaired communication and even ill-treatment". ${ }^{159}$ Perumel opines that given the recognised philosophical approach that children should be nurtured and develop within a parent- or family-based environment, residential care, whether it is short-term or long-term, must in all instances be considered as an interim means of care. ${ }^{160}$ The limited or lack of any emotional, psychological and physical support for a child placed in institutional care prevents a child from experiencing such support typically found in a family environment.

The primary role of child and youth care workers is to provide care and support for such children. However, care within a children's home cannot be viewed as equivalent to that within a family and therefore, as noted earlier, institutional care is generally viewed as the last option on the continuum of care, which stresses that a child should be placed in an environment that supports his or her growth and developmental imperatives, including social, psychological, cultural and physiological needs. ${ }^{161}$

156 Simula Developing an Evidence-Based Foster Mother Screening Tool 58.

157 Simula Developing an Evidence-Based Foster Mother Screening Tool 53.

158 Simula Developing an Evidence-Based Foster Mother Screening Tool 68.

159 Mudaley as referred to in Perumel and Kasiram "Children's Homes and Foster Care: Challenging Dominant Discourses in South African Social Work Practice" 2008 44(2) Social Work/Maatskaplike Werk 165.

160 Perumel Living in a Children's Home and Living in Foster Care: Hearing the Voices of Children and Their Caregivers (Master of Social Work (MSW) dissertation, University of KwaZulu-Natal) 200712.

161 Meintjies et al Introduction to South African Law: Fresh Perspectives 9. The authors list a number of concerns regarding the care of a child in a residential facility as follows: "[such care] threatens children's normal developmental processes, primarily through a lack of individual attention and opportunities for attachment with adults; Fails to transfer critical life- 
Following a survey by Meintjies et al, it became apparent that a large number of children in CYCCs were HIV-positive. ${ }^{162}$ This factor raises important considerations regarding the provision of adequate and appropriate care of the children concerned. Concerns include the adequacy of:

- the skills of the appointed caregivers;

- their training in relation to appropriately providing for the care of the children so infected;

- the continuity of caregivers in a particular CYCC; and,

- children's access to health services.

Meintjies et al note that in South Africa children are being cared for by people who are not qualified for the job. ${ }^{163}$ Caregivers have expressed the need to have training in how to deal with children who have experienced some form of trauma. Given that many children have experienced a loss of their parent or parents to HIV/AIDS, this is clearly an identified need by such caregivers. ${ }^{164}$ Cases were also reported of physical abuse, sexual molestation and emotional abuse, as well as neglect of children in children's homes by untrained staff members or fellow older children. ${ }^{165}$

Although it is true that the CA strongly emphasises the need to provide appropriate programmes that respond to the developmental and therapeutic needs of children in the centres, McKay believes that a child placed in a CYCC is generally a child who needs sensitive, individual attention, familiar surroundings and intellectual stimulation. ${ }^{166}$ While it is not guaranteed that the care needed by a child will be available in a CYCC, it is equally true that

skills to children, resulting in children being inadequately prepared to cope with life when they leave care and, in instances, predisposing care-leavers to antisocial behaviour; Results in children being dislocated from their families, their communities, and concomitantly, their cultural background and identity; resulting in problems of 'reintegrating' into society; Marginalises children from society, and is accompanied by experiences of stigma and discrimination; Frequently fails to respond to children's individual needs, characteristically prioritising the needs of institutional functioning; Exposes children to overcrowding and a lack of privacy; Frequently exposes children to increased illness, a lack of access to medical care, and/or education; Puts children at risk of sexual and physical abuse by residential care staff and older children, and in extreme circumstances has resulted in trafficking of children; Operates as a 'magnet' in poor neighbourhoods: i.e. residential care settings are used by poverty-stricken caregivers as an 'economic coping mechanism', resulting in children being placed there because of lack of access to resources, as opposed to a lack of suitable care"; European Parliament "Children Without Parental Care or at Risk of Losing it" (2003) http://www.europarl.europa.eu/hearings/20070417/libe/sos_children_en.pdf 5 (accessed 2017-06-06).

162 As referred to by Yorke The Experience of Caregivers in Registered Child and Youth Care Centres in Gauteng, South Africa, During the First 21 Years of Democracy (MA Counselling Psychology dissertation, University of Pretoria) 201520.

163 Meintjies et al Introduction to South African Law: Fresh Perspectives 38. The authors provide that some caregivers have a qualification to care, namely the Basic Qualification in Child Care. However, more often than not this is not considered a pre-requisite to be appointed to the position of caregiver in a CYCC. See also Yorke The Experience of Caregivers in Registered Child and Youth Care Centres in Gauteng, South Africa, During the First 21 Years of Democracy 15.

164 Yorke The Experience of Caregivers in Registered Child and Youth Care Centres in Gauteng, South Africa, During the First 21 Years of Democracy 15.

165 Ibid.

166 Mccay No Love nor Money: Institutional Child Care in South Africa (1994) 80. 
a depleted, deprived family environment where parents have died of AIDS cannot hope to provide for these needs. ${ }^{167}$ However, Casky believes that when considering the ever-increasing number of vulnerable children, the harm brought by institutionalisation outweighs the benefits that it provides to children. ${ }^{168}$

It is clear that the number of unregistered homes is mushrooming. ${ }^{169}$ As a consequence of non-registration, the services these homes provide are unmonitored and unsupported (financially or otherwise) by the government. ${ }^{170}$ Generally, commentators agree that care given in a CYCC in no way corresponds to the care generally found in a safe and caring family environment. There is also anecdotal evidence that the move to make institutions the primary response to and solution for, the many children in need of care is likely to cause long-term harm to such children. For example, Heron and Chakrabarti, referring to a child's right to parental care, state that no love, protection and care for children, regardless of how professional the offering person is, can substitute for that of the child's parents. ${ }^{171}$ The commentators note that many caregivers in CYCCs approach their caregiving responsibilities as professionals, rather than as parental figures. Children placed in CYCCs often face cultural neglect and institutional racism. As a consequence, such children are prone to have a low selfesteem. ${ }^{172}$

Constant changes in caregivers also negatively influence the potential for the child to form a secure attachment to a social worker concerned with the child's case due to a high turnover of staff. Consistency in care provides some form of security for the child. Bowlby's attachment theory confirms this, which states that children require a constant and predictable adult caregiver in and to whom they can invest emotionally and form an attachment. ${ }^{173}$ Healthy attachment is seen as a prerequisite for a child to develop in a healthy and confident way. ${ }^{174}$

67 Perumal and Kasiram 2008 44(2) Social Work/Maatskaplike Werk 162.

168 Casky "Keeping Children out of Harmful Institutions: Why we should be Investing in Familybased Care" https://www.savethechildren.org.uk/sites/default/files/docs/Keeping_Children_ Out_of_Harmful_Institutions_Final_20.11.09_1.pdf (accessed 2017-09-17).

169 Meintjies, Moses, Berry and Mampane Home Truths: The Phenomenon of Residential Care in the time of AIDS (2007) 1; Meintjies et al Introduction to South African Law: Fresh Perspectives report that "We have little more than an anecdotal picture of how the sector manifests in practice on the ground. In particular, little is known about less formal residential care provisioning, about residential care settings that do not conform neatly in their origins, form or function to conventional institutions and which tend not to be registered with the State as required by law."

170 Meintjies et al Introduction to South African Law: Fresh Perspectives 2.

171 Heron and Chakravarty Exploring the Perceptions of Staff towards Children and Young People Living in Community-based Children's Homes (2003) 99.

172 Malatji and Dube "Experiences and Challenges Related to Residential Care and the Expression of Cultural Identity of Adolescent Boys at a Child and Youth Care Centre (CYCC) in Johannesburg" 2017 53(1) Issue 7 Social Work/Maatskaplike Werk 120.

173 Zeanah, Berlin and Boris "Practitioner Review: Clinical Applications of Attachment Theory and Research for Infants and Young Children" 2011 52(8) J Child Psychol Psychiatry 819; Zeanah, Schauffer and Dozier "Foster Care for Young Children: Why It Must Be Developmentally Informed" 2011 50(12) J Am Acad Child Adolesc Psychiatry 1199.

174 Yorke The Experience of Caregivers in Registered Child and Youth Care Centres in Gauteng, South Africa, During the First 21 Years of Democracy (2015) 11. 
The question is whether institutionalisation is meeting the needs of the children placed in CYCCs. In most developing countries, institutions providing care for children and the aged are plagued by a lack of resources, often implying poor service delivery. ${ }^{175}$ The current approach seems to place focus and emphasis on OVCs' need for shelter, food and clothing, while in fact, children have a wider range of needs, most of which are not material, but emotional. In this regard, a progressive rethinking is needed to transform childcare facilities. The focus needs to be placed on relationships within the current system, particularly with reference to that between caregiver and child. Developmental programmes should cater for children's need to develop into social and cultural individuals, not only for physical growth. Unfortunately, and to the downfall of the children placed in institutions, it seems that many social workers believe that OVCs have quantifiable needs that can be resolved through institutional assistance. It is clear that care options that do not have limitations on the growth and development of children are preferable to institutionalisation. ${ }^{176}$

It has been argued that placing a child in a CYCC is fraught with impingements on the variable developmental processes of childhood. Casky is of the view that children institutionalised during their early years of growth and development may suffer immense developmental delays. ${ }^{177}$ Williamson and Greenberg confirm this opinion. ${ }^{178}$ These revelations and observations mirror the work of psychoanalysts such as Sigmund Freud who perceive future challenges in a child's adult life if he or she is not well nurtured in his or her childhood. The ill effects of institutionalisation on the emotional, psychological and developmental aspects of children are well documented. ${ }^{179}$

\section{5 (iv) Concerns with CHHs}

Rosa highlights the plight of children living in $\mathrm{CHHs}$ stating that these children are often forced to use a variety of strategies to survive and overcome the financial difficulties they face daily. The strategies include working, relying on support from relatives and non-relatives, and performing favours in exchange for support. Children living in $\mathrm{CHHs}$ are entitled to a CSG, which an adult must administer on their behalf.

175 Molepo Challenges and Coping Strategies of Child and Youth Care Workers in the South African Context (DPhil thesis, University of Pretoria) 201496.

176 Dozier, Zeanah, Wallin and Shauffer "Institutional Care for Young Children: Review of Literature and Policy Implications" 2012 6(1) Soc Issues Policy Rev 2.

177 Casky https://www.savethechildren.org.uk/sites/default/files/docs/Keeping_Children_Out_ of_Harmful_Institutions_Final_20.11.09_1.pdf (accessed 2017-09-17).

178 Williamson and Greenberg "Families, Not Orphanages Better Care Network" 2010 Working Paper 5.

179 Moulson, Shutts, Fox, Zeanah, Spelke and Nelson "Effects of Early Institutionalization on the Development of Emotion Processing: A Case for Relative Sparing?" 2015 18(2) Dev Sci 298-313; Van IJzendoorn, Palacios, Sonuga-Barke, Gunnar, Vorria, McCall, LeMare, Bakermans-Kranenburg, Dobrova-Krol and Juffer "Children in Institutional Care: Delayed Development and Resilience" 2011 76(4) Monogr Soc Res Child Dev 8; Maqoko HIV/AIDS Orphans as Heads Of Households: A Challenge To Pastoral Care (Master of Theology dissertation, University of Pretoria) 2006 iii; Bunkers, Cox, Gesiriech, and Olsonhildren, "Orphanages, and Families: A Summary of Research to Help Guide Faith-Based Action" (2014) 6. 
The phenomenon of children caring for themselves without any adult supervision has become a social problem. These minors have to provide for the family and take on the responsibilities of adults as their parents have passed and they have no relatives to take them in. Typically, the eldest child undertakes adult responsibilities and burdens as the caregiver for his or her siblings. This form of care arrangement remains controversial. It has been suggested that its existence is an indication that the traditional extended family care system is failing. Richter opines that $\mathrm{CHHs}$ are economically more vulnerable than adult-headed households as research indicates that income within a $\mathrm{CHH}$ is approximately $20-30$ per cent less than that of an adult-headed household.

In 2008, the DSD (Gauteng) requested that a report be conducted on the prevalence and experiences of $\mathrm{CHHs}$ in Gauteng. Although restricted to Gauteng, the report provides good insight into the plight of these children in South Africa. Following an investigation, the report concluded inter alia that since such children lack the presence of a parent in their lives, most of them have limited means to generate any form of income. As a result, they are unable to effectively sustain the household in which they live. Furthermore, the children of $\mathrm{CHHs}$ are more likely to suffer abuse and exploitation. The threat of poverty and the demands of survival are very real for many of these children. Many in this study reported multiple losses and traumatic events. This may leave residual trauma that appears to have received inadequate attention; a number of children reported persistent feelings of loss and disappointment. Children seem more likely to have access to physical and financial support than emotional support. ${ }^{180}$

In addition to the emotional strain on children living in $\mathrm{CHHs}$, the DSD (Gauteng) further reports on their health and nutrition. While such children do have access to health facilities, especially clinics, the DSD is concerned about how staff members treat the children of such clinics and health facilities. Most children in $\mathrm{CHHs}$ appear to have access to at least two meals per day. This is made possible with the assistance of the informal support systems within the communities concerned. However, these children are by no means food secure. Likewise, lacking proper adult care and protection, children in $\mathrm{CHHs}$ are more exposed to abuse and exploitation. ${ }^{181}$

The report states that half of the children living in $\mathrm{CHHs}$ are exempted from paying school fees, which makes it possible for them to continue their schooling. However, since the responsibility of support within the home rests largely on the shoulders of a child-head of the household, the consequences, burden and stress placed on such children cannot be overemphasised. The DSD reports that it was found that schools could play a more supportive role in this regard, particularly in light of the academic vulnerability of younger siblings. ${ }^{182}$

180 Department of Social Development "Child-Headed Households in Gauteng Province: A Survey of the Prevalence and Experiences of Families in Gauteng" (2008) xv.

181 Gaciuki "Child Headed Households The Emerging Phenomenon in Urban Informal Settlements" 2016 6(11) Kenya Developing Country Studies 94.

182 Gauteng Department of Social Development "Child-Headed Households in Gauteng Province: A Survey of the Prevalence and Experiences of Families in Gauteng" xvi. 
In relation to children living in $\mathrm{CHHs}$, Sloth-Nielsen refers to the judgment of the Constitutional Court in the Government of the Republic of South Africa $v$ Grootboom $^{183}$ case, where it was held that the State has a parental responsibility towards children who have no parents:

When children are orphaned or abandoned and thus find themselves without families, the responsibility for fulfilling their socio-economic rights rests squarely on the State. The State consequently has two distinct constitutional duties:

(1) It has a duty to ensure that children in child-headed households are linked with some form of parental, familial or institutional care.

(2) It has a duty to provide the resources necessary for the survival and development of the children.

One of the implications is that the State has a responsibility to provide financial assistance to $\mathrm{CHHs}$. While the children do (in theory) have access to social welfare grants in the form of a CSG, the report of the DSD (Gauteng) indicates that less than one-third of such children do in fact rely on the grants for their well-being. The reasons are not clear, but at least half of the children living in $\mathrm{CHHs}$ in Gauteng were reported to be living in absolute poverty. Mkhize undertook a study (restricted to CHHs in KwaZuluNatal) that highlighted the multiplicity of adult roles undertaken by the heads of $\mathrm{CHHs}$ out of necessity. The children who participated in the study indicated that carrying out these functions was stressful.

The South African Law Reform Commission has argued that children who care for other children should be eligible for the CSG and that, when these child caregivers are too young to manage the grant, a "household mentor" should be appointed to manage the CSG on the child's behalf.

\section{5 (v) Concerns with extended family care}

Notwithstanding the acceptance of, and importance of extended family care, it is evident, with the rapid increase in the number of children orphaned by HIV/AIDS over the past two decades that the extended family (the system of kinship care) has become overburdened and is not coping with the numbers of children in need of care. Despite the obligation on the government to provide alternative care for children deprived of parental care, the extended family system still bears the greatest burden in caring for affected children. However, the responsibility for caring for orphaned children often overextends the capacity of families to cope, and consequently, many extended family systems have been completely overwhelmed. ${ }^{184}$

Poverty plays a major role in the struggle for the extended family to meet the needs of the orphans or abandoned children in their care. Local and international non-governmental organisations (NGOs) have noted this crisis. ${ }^{185}$ Research carried out by the Child Institute in Cape Town revealed that South African kinship foster parents continue to live a life of poverty

183 Supra.

184 Thiele Exploring the Feasibility of Foster Care as a Primary Permanency Option for Orphans (2005) 1.

185 Motepe A Life Skills Programme For Early Adolescent Aids Orphans (2005) 145. 
despite the provision of FCGs. ${ }^{186}$ The continued capacity of the extended family to serve as a support system for the number of children in need of care in South Africa is uncertain. Generally, primary caregivers within the family are entitled to claim only a CSG and not the substantially larger FCG. Kinship caregivers today tend to be impoverished and often older, and less educated, and may themselves be subject to deteriorating health conditions. ${ }^{187}$

Furthermore, children in kinship care tend to be invisible to the State so that their situations cannot be properly monitored and their best interests cannot be safeguarded as contemplated under the CRC and the ACRWC. ${ }^{188}$ Children in kinship care face the risk of violation of their rights, violations that impact negatively on their proper growth and development. Blackie expresses her concern that many abandoned children are not benefiting from the formal child protection system, as many of the children abandoned are absorbed into the communities concerned. While the communities assist in many ways, it cannot be guaranteed that such children do not then become victims of child trafficking. ${ }^{189}$

Poverty is recognised as the biggest threat to human security. While social security is as Nkosi notes, "designed for the purposes of poverty prevention, poverty alleviation, social compensation and income distribution", 190 children and caregivers in kinship care (who form the majority of those in alternative care situations) receive little or no support from the State in the form of access to social protection interventions. Although a right to financial and material relief is now legally recognised following the judgment in SS v Presiding Officer, Children's Court, Krugersdorp, ${ }^{191}$ other concerns must be noted. For instance, it is debatable whether the placement of a young child in the care of an elderly grandparent does, in fact, serve the best interests of a child. ${ }^{192}$ While the support of the extended family is desirable in caring for abandoned and orphaned family members (particularly because these children are afforded the opportunity to remain within their home environment), it is not surprising that essential services such as education and health care for such children are often not within reach of an impoverished family's budget. ${ }^{193}$ This situation for the child is not

186 Meintjies, Budlender, Giese and Johnson Children 'In Need of Care' or in Need of Cash? Questioning Social Security Provisions for Orphans in the Context of the South African AIDS Pandemic (2003) 27.

187 Roby "Children in Informal Alternative Care" 2011 UNICEF 41.

188 Assim Understanding Kinship Care of Children in Africa: A Family Environment or an Alternative Care Option? 154.

189 Blackie http://www.adoptioncoalitionsa.org/wp-content/uploads/2014/05/Fact-SheetResearch-on-Child-Abandonment-in-South-Africa Final2.pdf.

190 Nkosi "An Analysis of the South African Social Assistance System as it applies to Children in Rural Communities: A Perspective from the Grootboom Case" 2011 26(1) South African Public Law.

191 Supra.

192 Norward and Williams "No Grandchildren Left Behind: Educational Issues Faced by Grandparents OshKosh University of Wisconsin" (2013) http://www.uwosh.edu/hst/?p=446 (accessed 2017-06-06).

193 Hall, Sambu, Berry, Giese, Almeleh and Rosa "South African Early Childhood Review" (2016) https://www.bettercarenetwork.org/sites/default/files/South\%20African\%20Early\%20 Childhood\%20Review\%202016.pdf 6, reports, "Poor households have a disproportionately large burden of care for young children. This includes situations where grandparents and 
compatible with South Africa's constitutional provisions and its international obligations in respect of the fundamental rights of the child.

Although many social workers do not feel it is necessary to subject biological relatives of a child in need of fostering to the same rigorous screening procedure imposed on prospective non-related foster parents, the literature suggests that foster placements with relatives are not always in the child's best interests. ${ }^{194}$ Sinclair and Wilson state:

"[G]ood foster carers are not produced by good organisation or strategic plans

[but] through accurate selection appropriate training, appropriate support, and,

in the hopefully rare cases where this is necessary, counselling out."195

Williamson, however, is of the view that the extended African family still has an important role to play in caring for OVCs. ${ }^{196}$ Although he recognises that the extended family is weaker now than it has ever been, ${ }^{197}$ "the revival of the old African tenets of the extended family hood are not to be ignored". $198 \mathrm{He}$ asserts that the community's resilience and spirit of community life should not be overlooked. The practice of ubuntu is recognised and practised in South Africa among African communities. ${ }^{199}$ However, it is submitted that the high incidence and devastating effects of HIV/AIDS in South Africa should not be underestimated.

\section{CONCLUSION}

The most significant protective factor available to most children are their parents and family in that they exercise the most influence on a child's development. Early responsive caregiving is key to the development of any child. However, many children in South Africa lack such parental care. As such, the various forms of impermanent alternative care as potential appropriate care have been considered in this article. Such placements usually provide a temporary solution for the predicament in which the child finds him- or herself. While the reunification of families and early intervention by authorities to prevent a child being removed from a family environment is a priority, the reality is that such reunification or prevention is frequently not a potential option and is often fraught with its own challenges, such as inadequate resources to carry out the reunification process. Another reality, not to be underestimated, is the impact that HIV/AIDS has had on the country and the families concerned. For children who are left parentless as a result of this disease, there is no family to return to. This article has

other family members care for the children of parents who must migrate to find work. Four million children under 6 years live in the poorest $40 \%$ of households. This is a relative poverty line, and there has been no significant change in the number of young children living in the poorest $40 \%$ of households since 2003."

194 Carter and Van Breda 2016 52(2) Social Work/Maatskaplike Werk 210.

195 Carter and Van Breda 2016 52(2) Social Work/Maatskaplike Werk 211.

196 Williamson "Caring for Orphans: A Child's Place is in a Family. Children First" 2002 6(44) Social Work/Maatskaplike Werk 24-25. See also Foster and Williamson "A Review of Current Literature on the Impact of HIV/AIDS on Children in Sub-Saharan Africa 2000 14(3) AIDS S275-S284.

197 This is as a consequence of the devastation of the HIV/AIDS epidemic.

198 Williamson 2002 6(44) Social Work/Maatskaplike Werk 24-25.

199 The term "ubuntu" can be translated as "we are who we are because of others". 
discussed alternative care in the narrow sense and has set out the advantages and many disadvantages of all forms of this type of alternative care.

While there have been significant innovations and improvements in the care and protection of children, it is submitted that the South African childcare and protection system has not fully achieved its overriding developmental purpose and objectives. The current reality in South Africa is that the majority of children in the country are vulnerable, and the child welfare system is failing in its role to promote and protect those children in need of care. In fact, the Department of Social Welfare and Development is in a state of crisis and does not have the capacity or skill to cope with the obligations it is faced with. The DSD is facing several legal cases that have been initiated against it. The reality in South Africa is that is has a child welfare system that has failed the children it was supposed to protect. Consequently, many children in South Africa do not enjoy their rights to survive, develop to their full potential, protection and participation.

While orphaned and abandoned children in South Africa have the right to appropriate alternative care, the difficulties a child faces when placed in temporary care, and the problems encountered with the present alternative care system leads one to seriously question the ability of the DSD in placing a child in appropriate alternative care that best serves the interests of such child. The lifetime effect such a placement has on any child concerned cannot be over-estimated, and as such, one ought to be able to rely on the skill and expertise of the relevant authorities in making such a determination. Instead, the pressing problems encountered within an inadequate child welfare system, have left the children in need of care in an extremely vulnerable position, and the system is obviously failing to protect and ensure the best interests for OVCs in South Africa. Consequently, not all legal decisions on placement are made in the best interests of the child concerned.

Although the provision and extension of social grants are improvements in the South African child welfare system, too little has been done to ensure that the vulnerable South African child's rights to family and parental care are protected, ensured and achieved. South African welfare services are evidently in disarray. Hall opines as follows:

"Our welfare services seem to be in disarray: they are under-capacitated in every way - not enough staff, not enough cars, offices without computers. The system is still largely paper-based, and this means that cases cannot be properly tracked or referred. The few social workers there are, are rushing around trying to deal with the foster care backlog, although this mainly involves orphaned children who are living quite safely with relatives. In the meantime, cases referred from SAPS are not followed up, and those are the really urgent ones - and only the tip of the iceberg as most cases of abuse don't get reported at all."

Too few staff, overburdened with high caseloads, has meant that those employed are unable to carry out their duties efficiently. Social workers are unable to be in regular contact with a foster child and foster parents. There is widespread concern that the response to increasing numbers of orphans from the AIDS epidemic in South Africa is leading to a proliferation of institutional care. Globally, institutional care emerged as a quick solution to 
the pressing problem of a multitude of OVCs; institutionalisation was accepted as a large-scale solution to the problem. ${ }^{200}$ However, the CRC states that residential care violates its own principles with reference to childcare. International principles of the child welfare sector are united in advocating residential care only as a temporary "last resort" for children. ${ }^{201}$ The South African government and other key players in the local child welfare sector confirm this position.

The current situation is untenable and neglects the rights and best interests of the child. It seems obvious that alternative care in the narrow sense is not providing the protection and ensuring of basic human rights as envisaged in terms of both national legislation and international instruments. Ignoring the system's defects, incapacities and limitations amount to inflicting lifelong harm on the children concerned. The authorities ought to consider other possibilities that would ensure that the best interests of the child are served. Where a permanent placement is acknowledged as a means of providing stability in the life of an OVC, the legislature and the judiciary ought to play a role in ensuring that a child's fundamental rights are promoted and protected. Failure to place a child in the most appropriate care is failing the child concerned. Serious concerns have been raised in the current chapter with respect to alternative care for an abandoned or orphaned child in South Africa. Viable solutions that cater for a child's best interest must be sought and effected.

The present state of the DSD is such that in reality very little can be effected to help the child in need of care in 2018. Financial and time constraints create an obstacle to effecting changes to the present child welfare system in South Africa. This leaves the OVC in South Africa trapped in a system that fails to acknowledge that other viable options are in fact the only appropriate placement for the burgeoning number of orphaned and abandoned children in South Africa.

A solution to the current crisis facing the child welfare system in South Africa obviously has a major impact on children reliant on the services of and placement by the DSD.

200 Kang'ethe and Makuyana "Exploring Care and Protection Offered to OVCs in Care Institutions with examples from South Africa and Botswana" 2015 Journal of Social Sciences 106.

201 Meintjies, Moses, Berry and Mampane "Home Truths: The Phenomenon of Residential Care for Children in a time of AIDS" https://open.uct.ac.za/bitstream/handle/ 11427/4094/Cl_researchreports_residentialcare_2007-06.pdf?sequence $=19$ (accessed 2017-09-27). 